\title{
SABELLID AND SERPULID WORMS (POLYCHAETA, CANALIPALPATA, SABELLIDA, SABELLIDAE, SERPULIDAE) FROM THE ROCKY COAST FACIES (LATE CENOMANIAN) AT PŘEDBOJ NEAR PRAGUE
}

\author{
TOMÁŠ KOČí \\ the Czech Republic; e-mail: protula@seznam.cz \\ MANFRED JÄGER \\ Lindenstrasse 53, D-72348 Rosenfeld, Germany, e-mail: langstein.jaeger@web.de
}

Palaeontological Department, Natural History Museum, National Museum, Václavské náměstí 68, CZ-115 79 Prague,

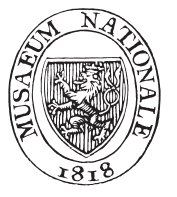

Kočí, T., Jäger, M. (2015): Sabellid and serpulid worms (Polychaeta, Canalipalpata, Sabellida, Sabellidae, Serpulidae) from the rocky coast facies (Late Cenomanian) at Předboj near Prague. - Acta Mus. Nat. Prague, Ser. B, Hist. Nat., 71(1-2): 31-50, Praha. ISSN 1804-6479.

Dedicated to RNDr. Olga Nekvasilová, CSc. and †MUDr. Vilém Lebenhart.

Abstract. The relatively rich assemblage of tube dwelling polychaetes including sabellid (Sabellidae) and serpulid (Serpulidae) worms (Polychaeta, Canalipalpata) from the classical rocky coast facies locality Předboj (Late Cenomanian - Early Turonian, Vltava-Beroun area, Bohemian Cretaceous Basin) is described in detail for the first time in a single publication. Ten genera: Glomerula, Filogranula, Neovermilia, Cementula, Laqueoserpula, Dorsoserpula, Placostegus, Pyrgopolon, Neomicrorbis, and Bipygmaeus are represented by 16 species, some of them are described in open nomenclature. Two of the species are new: Pyrgopolon (Septenaria) nekvasilovae sp. nov. and Pyrgopolon (Septenaria) zitti sp. nov. All species are described, and their systematics, taxonomy and palaeoecology are discussed.

Annelida, Polychaeta, Sabellidae, Serpulidae, taxonomy, palaeoecology, Late Cretaceous, Bohemian Cretaceous Basin.

Received April 24, 2015

Issued October, 2015

\section{Introduction}

Sabellid and serpulid worms are characteristic elements of the mesofauna of the rocky coast facies sites on the southwestern and southern border of the Bohemian Cretaceous Basin (BCB). During fieldwork between 1960 - 1968 at the classical rocky coast facies locality at Předboj, Dr. O. Nekvasilová collected 214 specimens of sabellid and serpulid worm tubes, some of them consisting of two or more tubes attached to each other. During recent relocation of some parts of the National Museum collections, the material collected by Nekvasilová attracted attention again. Some specimens from this locality had already been briefly mentioned by Ziegler (1984), included in a faunal list by Žítt et al. (1999), and in preliminary reports by Kočí $(2012 b, c)$. The fauna consists of 10 genera represented by 16 species, some of them are described in open nomenclature. Two of the species are new: Pyrgopolon (Septenaria) nekvasilovae sp. nov. and Pyrgopolon (Septenaria) zitti sp. nov. The sabellid and serpulid worm tubes from the rocky coast facies deposits of the BCB were studied recently by Jäger and Kočí (2007), Kočí (2007a, b, 2009a, b, 2010, 2011, 2012a, b, c), and those from hemipelagic facies deposits of the BCB were studied by Sklenár et al. (2013).

\section{Geological and geographical settings}

In the Předboj area there were several outcrops (see Žítt et al. 1999) showing geological sections and yielding more

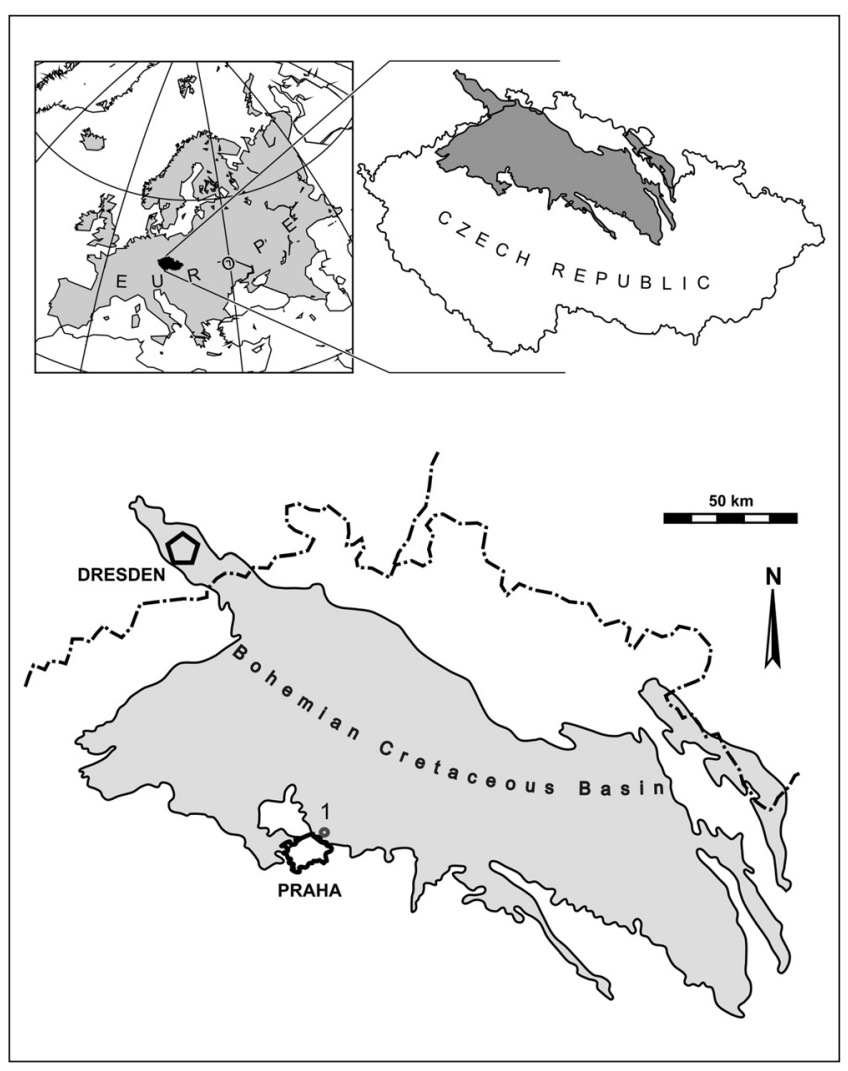

Text-fig. 1. Geographical position of the locality Předboj in the Bohemian Cretaceous Basin and in Europe. 
or less abundant macrofauna. Text-fig. 1 shows the (palaeo-) geographical situation of the Předboj area within the context of Europe. Text-fig. 2 shows the stratigraphical profile at Předboj (slightly modified after Žítt et al. 1999).

The classical locality at Předboj is named outcrop A. This former quarry had been filled in during the $1960 \mathrm{~s}$. It is situated north of Prague, just east of the road from Předboj to Horňátky, circa $300 \mathrm{~m} \mathrm{NNE}$ from the triangulation point $213 \mathrm{~m}$ above sea level. The site forms part of Unhošt'-Tursko High (Žítt et al. 1999). Here, boulders and smaller pieces of rock broken down from a massive cliff of Late Proterozoic lydites were deposited in a depression shaped by abrasion by the Cretaceous sea, and formed a conglomerate. This basal conglomerate including material trapped in-between finergrained Cretaceous sediments and the overlying thin Cretaceous marlstones were preserved from later erosion. In the highest part of the basal conglomerate (Svoboda 1984) and probably also above the conglomerate, guards of the index belemnite Praeactinocamax plenus (BLAINVILLE, 1827) were found. Geology and stratigraphy of the Předboj site was described in detail by Žítt et al. (1999).

\section{History of palaeontological research at Předboj}

Prantl (1929, 1938) and Zázvorka (1939, 1944a, b) were the first authors who mentioned the Předboj locality. Klein (1952) and later Svoboda (1982, 1984) carried out geological and palaeontological research at this locality. Backhaus (1959) studied thecideid brachiopods, Nekvasilová and Prokop (1963) roveacrinid crinoids, Nekvasilová (1964, 1967, 1993) thecideid and terebratulid brachiopods, Ziegler (1984) serpulid worms, geology and palaeontology, Voigt (1989) bryozoans, Žítt (1993) regular echinoids, Žítt and Nekvasilová (1993) octocorals, Záruba (1998) oysters, and Žítt and Geys (2003) saleniid echinoids. Žítt et al. (1999) published detailed geological, palaeontological and palaeoecological data and included a faunal list of the Předboj site.

In his monograph on sabellid and serpulid worm tubes from rocky coast facies localities of the BCB, Ziegler (1984) presented photographs of the following species from the Early Turonian of Předboj; here we include their names as published by Ziegler (1984) as well as their revised actual names after study of the original specimens in the NM: Martina parva ZIEGLER, 1984 (specimen NM-O5117) belongs to Dorsoserpula bipartita (REUss, 1845). The original figured specimen of Pomatoceros triangularis (Münster in Goldfuss, 1831) was not found in the collection, but another specimen was present and belongs to Neovermilia cf. ampullacea (J. DE C. Sowerby, 1829). One of the two figured specimens of Eoplacostegus dentatus (BRÜNNICH NIELSEN, 1931), specimen NM-O5388 figured on P1. 5, Fig. 7, is from Předboj, although this locality is not mentioned in the locality list of this species, the specimen belongs to Placostegus zbyslavus (ZIEGLER, 1984). All these revised species are also described in the present paper.

Moreover, Ziegler listed the following species as occurring in the Early Turonian at Předboj, but the figured specimens of these species were found at other localities, so the correctness of the determination of the non-figured specimens from Předboj can not be confirmed by study of the figured specimens only: Glomerula gordialis (VON SCHLOTHEIM, 1820), Glomerula solitaria REGENHARDT, 1961 and Serpula prolifera GOLDFUSS, 1831 belong to Glomerula serpentina (GolDFUSS, 1831). Glomerula scitula REGENHARDT, 1961 and Spiraserpula subinvoluta (REUSS, 1844) belong to Glomerula lombricus (DefRAnCE, 1827). Sarcinella plexus (J. DE C. SowerBy, 1829) belongs to Filograna socialis (GolDFUSS, 1831). Serpula antiguata [sic!] J. DE C. SOWERBY, 1829 and Proliserpula ampullacea (J. DE C. SOWERBY, 1829) belong to Neovermilia cf. ampullacea (J. DE C. SowerBY, 1829). The two figured specimens of Spiraserpula spirographis (GOLDFUSS, 1831 ) belong to Glomerula serpentina (GoLDFUSS, 1831) and Laqueoserpula reussi (WEINZETTL, 1910), respectively. The figured specimen (NM-O5382) of Pomatoceros biplicatus (REUSS, 1844) is not a serpulid at all, but an octocoral. Hamulus hexagonus (RoEMER, 1841) is not figured and can not be judged without studying the original specimen. Spirorbis asper (VON HAGENOW, 1840) belongs to Dorsoserpula bipartita (REuss, 1845). Spirorbis margarita ZIEGLER, 1984 and Spirorbis milada ZIEGLER, 1984 belong to Neomicrorbis crenatostriatus subrugosus (MÜNSTER in GOLDFUSS, 1831). From these revised species, all except Glomerula lombricus, Filograna socialis and Pyrgopolon (Hamulus) hexagonus, which we did not see in the Nekvasilová collection from Předboj, are also described in the present paper.

A preliminary brief report of sabellid and serpulid worms from Předboj was published recently by Kočí (2012b, c).

\section{Material and methods}

The studied and described material was collected by Dr. Olga Nekvasilová during field work between $1960-$ 1968. All this material is deposited in the collections of the National Museum in Prague. The specimens were studied under a binocular microscope $(20 \mathrm{x}-40 \mathrm{x}$, Bresser) and photographed with a Canon EOS 550D and some of them by use of the microphotography setting on an Olympus DP70. Plates were prepared using Corel Graphic Suite X4. The figured specimens are kept in the collection of the National Museum at Prague, numbered NM-O7544 - O7573.

\section{Systematic palaeontology}

Classification of sabellids and serpulids (including spirorbins) follows Brünnich Nielsen (1931), Regenhardt (1961), Ware (1975), Lommerzheim (1979), Jäger (1983, 2005, 2011, 2012, 2014), Ziegler (1967, 1974, 1978, 1984), Pillai (1993), Radwańska (1996), ten Hove and Kupriyanova (2009) and Ippolitov et al. (2014).

Class Polychaeta Grube, 1850

Infraclass Canalipalpata RouSE et FAUCHALD, 1997

Order Sabellida FAUCHALD, 1977

Family Sabellidae LATREILle, 1825

Subfamily Sabellinae CHAMberLIN, 1919

Glomerula BRÜNNICH NIELSEN, 1931

Glomerula serpentina (GoLDFUSS, 1831)

$$
\text { P1. 1, Fig. } 1
$$

1831 Serpula gordialis SCHLOTHEIM Varietas serpentina - Goldfuss, p. 240, pl. 71, fig. 4. 
1840 Serpula implicata nob. - von Hagenow, p. 668, pl. 9, fig. 17.

1846 Serpula serpentina GoldFuss - Reuss, p. 106, pl. 42, fig. 22.

1911a Serpula gordialis, var. serpentina - Frič: p. 72, fig. 304.

1911b Serpula gordialis, var. serpentina - Frič, p. 72, fig. 304.

1961 Glomerula solitaria n. sp. - Regenhardt: p. 28, pl. 9, fig. 11.

1961 Protula rasilis n. sp. - Regenhardt, p. 33, pl. 1, fig. 7.

1961 Omasaria omnivaga n. sp. - Regenhardt, p. 45-46, pl. 5 , fig. 7.

1984 Glomerula gordialis (SCHLOTHEIM, 1820) Ziegler, p. 215-216, pl. 1, fig. 3-5.

2005 Glomerula serpentina (GOLDFUSS, 1831) - Jäger, p. 130, pl. 1, fig. 1.

2011 Glomerula serpentina (GoLDFUSS, 1831) - Jäger, p. 680-681, pl. 1, fig. 1-7.

2012a Glomerula serpentina (GOLDFUSS) - Kočí, p. 8-9, pl. 1, fig. 1.

2012b Glomerula serpentina (GoldFuss) - Kočí, p. 120-122, fig. 1A.

2014 Glomerula serpentina MÜNSTER in GOLDFUSS [sic!] - Jäger, p. 60, fig. 1d.

Materia 1: 40 planispiral specimens, 8 specimens forming glomerulate knots, 74 tube fragments.

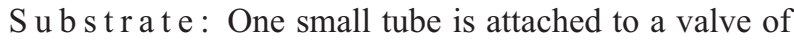
the oyster Amphidonte (Amphidonte) reticulatum (REUSS, 1846), another specimen to an Ostrea sp., and a third one to a pectinid valve.

Description. The tube is coiled to form either glomerulate knots or planispirals. The surface of the tube is smooth without any ornamentation. The tube diameter ranges from 1 to $2.7 \mathrm{~mm}$, usually from 1.3 to $2.2 \mathrm{~mm}$, and in most specimens it measures circa $2 \mathrm{~mm}$. The cross-section of the tube as well as the cross-section of the lumen is circular.

Remarks and relationships. The genus Glomerula ranges from at least the Hettangian to the Recent, and it is common and geographically widespread from the Late Toarcian until the Eocene. Possible Triassic or even Late Palaeozoic representatives of Glomerula are mentioned by Ippolitov et al. (2014). Glomerula serpentina is often a common species in rocky coast facies of the Cretaceous period.

As discussed by Jäger (2005) and Sklenář et al. (2013), distinguishing species of Glomerula is problematic, due to the simple morphology of the tubes which display only a limited number of morphological features and the large variability even within one sample, therefore the schemes presented in previous papers are certainly in part artificial. The occassional presence of trilobate lumina can be used as a feature for taxonomic discrimination between a set of Cretaceous Glomerula species from a more ancient set of Jurassic Glomerula species (Jäger 2005) which totally lack trilobate lumina. However, a trilobate lumen was not observed by us in thespecimens from Předboj. Within the set of Cretaceous Glomerula species, the usually relative large and usually solitary $G$. serpentina is the most common. Clusters composed of dozens or even more than a hundred Glomerula tubes occurring mainly in the Santonian and Campanian of South Sweden, North Germany, and England (type area) may be separated taxonomically and determined as G. plexus (J. DE C. SowerBy, 1829). Only in fine-grained offshore facies it has proven useful to separate specimens with a small tube diameter as Glomerula lombricus (DEFrAnCE, 1827).

\section{Family Serpulidae RAFINESQUE, 1815}

\section{Filogranula LANGERHANS, 1884}

\section{Filogranula cincta (GoLdFuss, 1831)}

Pl. 1, Fig. 6

1831 Serpula cincta nobis - Goldfuss, p. 237, pl. 70, fig. 9a-c.

1983 Filogranula cincta (GoLdFUSS, 1831) - Jäger, p. $68-71$, pl. 8, fig. 8-13.

1996 Filogranula cincta (GoldFuss, 1831) - Radwańska, p. 71, pl. 8, fig. 1-6.

2005 Filogranula cincta (GoLDFUSS, 1831) - Jäger, p. 151, pl. 2, fig. 10-13.

2007b Filogranula cincta (GolDFUSs) - Kočí, p. 112113, fig. 1-2.

2011 Filogranula cincta (GoLdFuss, 1831) - Jäger, p. 686, pl. 4, fig. 1.

2012b Filogranula cincta (GoldFUss) - Kočí, p. 122, fig. $1 \mathrm{~F}$.

Materia l: One specimen.

Substrate: No substrate is preserved.

Description. The tube is $7 \mathrm{~mm}$ long. The tube diameter is $1.8 \mathrm{~mm}$ at the posterior trapezoidal cross-section and $1.2 \mathrm{~mm}$ at the aperture. The upper side of the tube bears three cocks' comb-like longitudinal ridges. The lumen is circular.

Remarks and relationships. Filogranula cincta resembles three Late Cretaceous species: Vermiliopsis fluctuata (J. DE C. SowerBY, 1829), Metavermilia (Vepreculina) fimbriata REGENHARDT, 1961 and Serpula? trilineata ROEMER, 1841. Vermiliopsis fluctuata has an extra two longitudinal ridges and is heptangular in cross-section, its aperture does not show any strong tendency to grow upwards. The latter is also true for Serpula? trilineata which erroneously was affiliated to the genus Janita SAINT-JOSEPH, 1894 by Jäger (1983). Moreover, Serpula? trilineata has weaker longitudinal ridges and delicate transverse ornamentation. Metavermilia (Vepreculina) fimbriata, of which only the free tube portion is known, has a smaller tube diameter of only $0.7-1.0 \mathrm{~mm}$, and a variable number of often granulose longitudinal ridges which occur all around the tube.

Like Filogranula cincta, the Recent Crucigera websteri BENEDICT, 1887 has three irregularly undulating longitudinal keels that may reach $1.4 \mathrm{~mm}$ in height. Its tube differs in its circular cross-section, greater width which may reach $5.5 \mathrm{~mm}$ including the keels, and by the fact that in juvenile specimens the base of the keels may be perforated. Sometimes there is 
a pair of faintly developed longitudinal ridges near the base of the tube. Terminal flaring peristomes or collar-like rings have not been observed (ten Hove and Jansen-Jacobs 1984).

According to Lommerzheim (1979) who considered Filogranula cincta a synonym of Vermiliopsis fluctuata and combined them under the name Filogranula fluctuata, the present species lived in an ecologically wide range of marine shelf environments from the littoral down to a water depth of circa 200 m. Jäger (1983) confirmed the wide ecological range of Filogranula cincta. This species was attached to various kinds of hard substrate (pieces of rock, coral sceletons, sponges, shells, filiform stems of algae). The detailed palaeoecogical relationships were mentioned by Kočí (2007b). According to Zibrowius (1968), Recent representatives of the genus Filogranula live in the Mediterranean Sea and northeastern Atlantic at depths of 15-1780 metres, prefering deep, calm habitats, even though some specimens also live in water currents. In the Mediterranean Sea, Filogranula is also common in submarine caves in relatively shallow water, even in the darkest and most remote parts. Other species of Filogranula live at Brazil and Japan.

\section{Neovermilia DAY, 1961}

\section{Neovermilia cf. ampullacea (J. DE C. SOWERBY, 1829)}

\section{Pl. 1, Fig. 2; Pl. 3, Fig. 3; Pl. 4, Fig. 1}

2012b Neovermilia ex gr. ampullacea (SOWERBY) Kočí, p. 122, fig. 1B.

2014 Neovermilia cf. ampullacea (SowERBY, 1829) Jäger, p. 66, fig. 2c.

Material: Three fragments of the anterior tube portion.

Substrate: No substrate is preserved, but vice versa one of the tubes (Pl. 3, Fig. 3) is encrusted by membranipore bryozoa.

Des c ription. The tube is circular in cross-section and measures 3-9 $\mathrm{mm}$ in diameter. An annular peristome, characteristic of Neovermilia ampullacea, is present.

Remarks and relationships. The genus Neovermilia first occurred in the Late Oxfordian (Radwańska, 1996). Neovermilia is common in the coarse-grained rocky coast facies sites in the BCB, e.g. Velim, Kamajka near Chotusice, Kaňk - Na Vrších, etc. Tube morphology is quite variable, making a useful discrimination between species nearly impossible. Some specimens bear a sharp longitudinal keel, whereas other specimens have no keel but a tube with a circular cross-section. Many specimens of the genus Neovermilia possess hollow "tubulae" (two small longitudinal canals near the borders of the tube's base; compare e.g. Thomas 1940, Hedley 1958, fig. 9, Jäger 1983, fig. 2, Vinn and Wilson 2010, fig. 4, Sklenář et al. 2013, Ippolitov et al. 2014). In the genus Neovermilia, the tubulae are cellular and composed of shorter cells than in the genera Spirobranchus BLAINVILle, 1818 and Pyrgopolon DE MONTFORT, 1808.

Formerly, Neovermilia ampullacea had been attributed to the genus Proliserpula REGENHARDT, 1961, but according to Jäger (2005) Proliserpula is a subjective synonym for

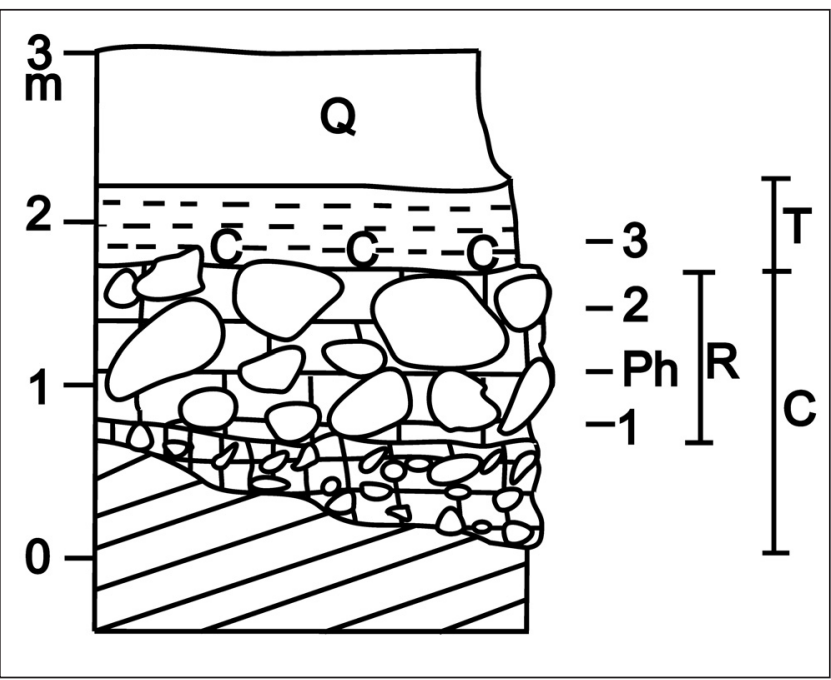

Text-fig. 2. Stratigraphical section at Předboj (according to Žítt et al. (1999), modified). Legend: 1 - Proterozoic bedrock, 2 - conglomerate, 3 - marl, marlstone, $\mathbf{P h}$ - phosphatic crusts, R - reworked deposit, C - Upper Cenomanian, T - Lower Turonian, Q - Quaternary deposits, c - occurrence of invertebrate coprolites.

Neovermilia. The shape and structure of the tube in the Plio-Pleistocene to Recent species Neovermilia falcigera (Roule, 1898) (see Zibrowius and ten Hove 1987, fig. 2) is very similar to that of the Cretaceous specimens except that $N$. falcigera has no keel, weaker transverse ornamentation and a thick tube wall. However, a strong keel and delicate transverse ornamentation are present in another Recent Neovermilia species, N. globula (DEw, 1959).

The fossil genus Propomatoceros WARE, 1975 is usually triangular or rounded triangular in cross-section. Although some specimens of Neovermilia are also triangular in cross-section, this genus is usually more rounded with tunnel-shaped or circular cross-sections.

Ziegler $(1974,1984)$ described the present species from many nearshore localities of the Late Cenomanian to the Middle Turonian of the BCB, whereas specimens of $N$. ampullacea sensu stricto from the offshore locality Úpohlavy were described and discussed by Sklenár et al. (2013).

\section{Cementula REgEnHARDT, 1961}

\section{Cementula sp.}

$$
\text { Pl. 1, Fig. } 11
$$

2012b Cementula sp. - Kočí, p. 123, fig. 1L-M. non 2012b Cementula sp. - Kočí, p. 120, fig. 1J-K.

Material: Twenty-two complete specimens and 12 fragments.

Substrate: This species shows a tendency to form small clusters composed of several Cementula tubes attached to each other.

Description. The tube is slightly depressed, has a wide basal seam, and forms somewhat irregular, more or less compact loops and coils, although rarely regular spirals, 
using its own anterior tube portions as a substrate. Except for a small and low but distinct median keel and a few alae-shaped peristomes present in some specimens, the surface of the tube is smooth and tends to obscure the boundary lines between the separate whorls by calcareous tube material laid over them. The umbilicus is narrow and often obscured by a filling of sediment. Internal tube structures ("ITS"; Pillai 1993) are absent.

Remarks and relationships. Loops and coils are less regular compared to the regular spirals common in other Late Cretaceous Cementula species, e.g. C. spirographis (GoldFuss, 1831) and C. depressa (GoldFuss, 1831), both from the Middle Cenomanian of Essen, and the single find of a Cementula spiral system from the Late Cenomanian of Saxony (Jäger 2014); the two last mentioned forming large systems of planar spirals attached to large oyster valves. The spirals of Cementula sphaerica BRÜNNICH NiELSEN, 1931 from Middle Santonian to Late Maastrichtian are also more regular, planar or more or less hemisphaerical in shape, and most of them lack an umbilicus. The Late Campanian and Maastrichtian species of the closely related genus Spiraserpula REGENHARDT, 1961 differ by the presence of "ITS" (Pillai 1993).

Fossil representatives of Spiraserpula and Cementula (e.g. Goldfuss 1831, Brünnich Nielsen 1931, Regenhardt 1961, Lommerzheim 1979, Jäger 1983, 2005, Pillai 1993) occur mainly in shallow-water facies including Late Cretaceous sites from rocky coast and coral reefs down to relatively shallow portions of chalk facies circa $200 \mathrm{~m}$ deep (Lommerzheim 1979), Danian bryozoan limestone facies, and Danian non-zooxantellate coral facies (Brünnich Nielsen 1931). The 19 Recent species (including one in open nomenclature) of the genus Spiraserpula were described in detail by Pillai and ten Hove (1994) who are also the authors of all Spiraserpula species mentioned below except S. massiliensis (ZIBrowiUs, 1968). Here we provide a compilation of their ecological data: Spiraserpula occurs at various depths and inhabits various substrates, but only a few species can be called deep water species, e.g. $S$. capeverdensis which lives around the Cape Verde Islands at depths of 75-200 $\mathrm{m}$ where the sea-floor consists of coarse sand, shell gravel, calcareous stones, calcareous nodules, calcareous algae and sponges. Both $S$. deltoides and S. sumbensis were found only near Sumba, Indonesia on calcareous stones at depths of about 75-90 m. S. vasseuri was found on oyster shells in a submarine cave at a depth of $55 \mathrm{~m}$ near Europa Island in the Mozambique Channel. However, most Spiraserpula species live in warm shallow waters, e.g. $S$. massiliensis in the Mediterranean Sea and northeastern Atlantic and S. ypsilon near the Cape Verde Islands. In sheltered habitats (submarine caves, overhangs, under stones) they occur in shallow water down to circa $20 \mathrm{~m}$, and on the open sea-floor (in Caulerpa meadows or/and on shells, calcareous algae and concretions) they live in circa 15-60 m, whereas finds at deeper sites are probably transported dead tubes. S. ypsilon and many other Spiraserpula species live in or near coral reefs from the intertidal (rock pools) to less than $50 \mathrm{~m}$ deep, many somewhat sheltered on the underside of rocks or coral debris, but some exposed to strong water action. Most species are not widely distributed geographically, some are even endemic to a small area.
Among tropical coral reef sites inhabited by one or more Spiraserpula species, those situated in the Caribbean and in the Gulf of Mexico are mentioned most frequently, e.g. Bonaire, Curaçao, Florida, and others, but also Indonesia (e.g. Flores Sea) and Australia (New South Wales, Queensland). S. caribensis is widely distributed in the Caribbean and Gulf of Mexico from Florida to Barbuda and Panama; it lives intertidally down to $10 \mathrm{~m}$ in the Caribbean and to $18 \mathrm{~m}$ in the Eastern Gulf of Mexico. It occurs in a variety of habitats, from rockpools to the undersides of boulders in mangrove glades; it survives well in somewhat muddy, but always cryptic environments between boulders, coral debris, shells or other solid substrates. S. snellii is a reef dweller, often attached to corals, it occurs at depths of 2$30 \mathrm{~m}$, and appears to be the most widely distributed species of the genus: northern Red Sea, Indonesia (Flores Sea), Australia (Great Barrier Reef), and Western Pacific (South Japan to New Caledonia).

\section{Laqueoserpula LOMMERZHEIM, 1979}

\section{Laqueoserpula reussi (WEINZETTL, 1910)}

\section{Pl. 1, Fig. 7}

non 1831 Serpula depressa nobis - Goldfuss, p. 236-237, pl. 70, fig. 6 .

1875 Serpula depressa GoldFuss - Geinitz, p. 286, pl. 63, fig. 22 .

1910 Burtinella(?) Reussi m. - Weinzettl, p. 23-24, pl. 3, fig. 46, 47, and 51. (NM-O3537, O3538, and $\mathrm{O} 3539$ )

1979 Laqueoserpula cf. plana n. sp. - Lommerzheim, p. 150.

1984 Spiraserpula spirographis (GoldFuss, 1831) and Mucroserpula arcuata (MÜNSTER, 1831) Ziegler, p. 225, pl. 3, fig. 7. (NM-O5377)

1984 Mucroserpula arcuata (MÜNSTER, 1831) Ziegler, p. 228-229, pl. 4, fig. 3-4. (NM-O5379, O5380)

1984 Mucroserpula mucroserpula REGENHARDT, 1961 - Ziegler, p. 229, pl. 4, fig. 5. (NM-O5381)

1984 Eoplacostegus sulcatus (SOWERBY, 1829) Ziegler, p. 235-236, pl. 5, fig. 8. (NM-O5167, not O5389, as erroneously stated by Ziegler (1984, p. 253))

1984 Hepteris septemsulcata (RoEMER, 1841) - Ziegler, p. 240-241, pl. 7, fig. 3-4. (NM-O5397)

1984 Hamulus sexsulcatus (MÜNSTER, 1831) - Ziegler, p. 240, pl. 7, fig. 5. (NM-O5398)

2006 Serpula cf. rauca ZIEGLER - Žítt et al., p. 66, fig. 12M.

2012b Laqueoserpula sp. - Kočí, p. 122, fig. 1G.

2014 Laqueoserpula reussi (WEINZETTL, 1910) - Jäger, p. 67, fig. 2d1-3.

non 1910 Burtinella (?) Reussi m. - Weinzettl, p. 23-24, pl. 3 , fig. 48,49 , and 50 .

Materia 1: Three complete specimens, one damaged coil and four fragments.

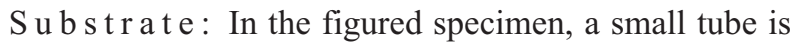
attached to a larger tube of the same species. 
Description. The attached posterior tube portion forms a coil, whereas the free anterior tube portion is elevated and slightly spindle-shaped. In a well preserved specimen which has a spine over the aperture, the attached coil measures $6.4 \mathrm{~mm}$ in diameter, and the free anterior portion reaches a tube diameter of $3.9 \mathrm{~mm}$. Longitudinal ornamentation consists of distinct lines on the upper side resembling tiny grooves. Transverse ornamentation consists of strong annular peristomes and distinct V-shaped wrinkles forming a spine over the aperture in one specimen, whereas in two other specimens such a spine is not present. Quadrangular cross-section.

Remarks and relationships. It may be speculated if the one specimen with a spine over the aperture and the two specimens lacking such a spine may belong to two different species, L. reussi and L. plana LOMMERZHEIM, 1979 , respectively. However, the more likely explanation is that the spines may have simply broken off. This alternative explanation is supported by the fact that in a detailed revision and description of this species from other rocky coast facies localities of the BCB which will be published by Jäger et al. (in prep.), all well preserved apertures usually bear spines. The angular tube morphology bearing spines at the aperture somewhat resembles that of the genus Placostegus PHILIPPI, 1844, however, typical representatives of Placostegus are smaller and have a translucent tube.

\section{Dorsoserpula PARSCH, 1956}

\section{Dorsoserpula bipartita (REUSS, 1845)}

Pl. 1, Fig. 3, 4, 5, 9, 10; Pl. 3, Fig. 2

1845 Serpula bipartita REUSS - Reuss, p. 19, pl. 13, fig. 95a-b.

1875 Serpula Gamigensis GEINITZ - Geinitz, p. 286-287, pl. 63, fig. 19-21.

1984 Sarcinella minor nov. spec. - Ziegler, p. 220-221, pl. 2, fig. 4.

non 1984 Sarcinella minor nov. spec. - Ziegler, p. 220-221, pl. 2 , fig. 5 .

1984 Martina parva nov. spec. - Ziegler, p. 227-228, pl. 3, fig. 9.

1984 Spirorbis asper (VON HaGeNOw), 1840 - Ziegler, p. 242, pl. 7, fig. 6. (NM-O5400)

1984 Spirorbis subrugosus (MÜNSTER), 1831 - Ziegler, p. 244, pl. 8, fig. 2. (NM-O5401)

1984 Spirorbis superminor nov. sp. - Ziegler, p. 244245, pl. 8, fig. 3. (NM-O5159)

2005 Dorsoserpula bipartita (REuss, 1845), syn. gamingensis [sic!] (GEINITZ, 1873 [sic!]) - Jäger, p. 162.

2007a Dorsoserpula gamigensis (GEINITZ, 1875) - Kočí, p. 109-110, fig. 5.

non 2009a Dorsoserpula gamigensis (GEINITZ, 1875) - Kočí, p. 98 , fig. 7 .

2009b Dorsoserpula gamigensis (GEINITZ) - Kočí, p. 209, 214, 218-220, fig. 3.

non 2012a Dorsoserpula gamigensis (GEINITZ) - Kočí, p. 10, pl. 1 , fig. 6.

2012b Dorsoserpula gamigensis (GEINITZ, 1875) - Kočí, p. 122, fig. 1C, D. p. 122 , fig. 1E, I, O.

2012b Cementula sp. - Kočí, p. 120, fig. 1J-K. non 2012b Cementula sp. - Kočí, p. 123, fig. 1L-M.

2014 Dorsoserpula bipartita (REuss, 1845) - Jäger, p. 70 , fig. 2 g1-5.

M a t e r i a 1: Six complete or nearly complete tubes, one damaged coil, two juvenile tubes and two fragments.

Substrate: Two tubes are attached to oyster valves. Two other tubes are attached to dorsal valves of the brachiopod Phaseolina phaseolina (VALENCIENNES in LAMARCK, 1819). Three tubes are attached to, and one of these is coiled around, separate tubes of Placostegus rigidus. Another specimen had originally been attached to an unknown substrate which is no longer present, maybe a crinoid stem or a stem of an alga. A small circular tube, maybe the additional tube characteristic for the genus Dorsoserpula ("Nebenröhre"; see Jäger 1983, p. 39), a juvenile serpulid tube or an overgrown stem of an alga, is laterally attached to the anterior portion of this specimen.

D e s c r i p ti o n. Usually the tube is almost planispirally coiled and consists of two to three whorls. However, a few tubes, especially in the posterior tube portion, are nearly straight or curved or low trochospiral. Tube diameter ranges from 0.9 to $2.5 \mathrm{~mm}$, and coil diameter ranges from 2.7 to $5.5 \mathrm{~mm}$. There is a delicate but sharp and distinct keel which may be slightly undulating on top of the tube, respectively at the periphery of the coil, and some of the larger tubes possess two additional but less distinct lateral keels which start only in the posterior part of the coil, but don't extend to the aperture of the tube. A smaller specimen has only one lateral keel. Apart from the keels, the surfaces of most tubes appear to be relatively smooth, but under the microscope very delicate, almost indistinct transverse wrinkles are visible. In one specimen, transverse ornamentation is curved forward, similar to the letter "V" turned upside down. The cross-section of the tube and the lumen are circular.

Remarks and relationships. Jäger (2005) previously considered $D$. gamigensis (GEINITZ, 1875) a junior subjective synonym of $D$. bipartita, but, however, did not decide if these Late Cenomanian to Early Turonian forms should be synonymized or not with $D$. wegneri (JÄGER, 1983) which is wide-spread mainly in the younger portion of the Late Cretaceous. After studying specimens from the BCB, Jäger (2014) concluded that D. bipartita and D. wegneri were two closely related but separate species, differing by size $(D$. bipartita remains smaller), by the rarity (but not total absence!) of a keel in subspecies D. wegneri wegneri, whereas $D$. bipartita usually (but not in every specimen!) has a keel, and by geological age ( $D$. wegneri wegneri is now considered to exist only from the Middle Turonian onwards). Some specimens from Předboj earlier (Kočí 2012b) determined as Dorsoserpula wegneri are affiliated to $D$. bipartita here due to their small size, presence of a keel and relatively old geological age.

After a long gap in geological time, keeled forms became common again in the Maastrichtian and were considered by Jäger (2005) to be a separate subspecies, D. wegneri 
maastrichtensis JÄGER, 2005, differing from D. bipartita mainly by possession of cellular tubulae.

\section{Placostegus PhILIPPI, 1844}

\section{Placostegus zbyslavus (ZIEGLER, 1984)}

\author{
Pl. 1, Fig. 8
}

1984 Eoplacostegus dentatus (NIELSEN), 1931 Ziegler, p. 235, pl. 5, fig.6-7. (NM-O5387 and O5388)

1984 Eoplacostegus zbyslavus nov. spec. - Ziegler, p. 236, pl. 6, fig. 1-2. (NM-O5390)

2009a Placostegus zbyslavus (ZIEGLER, 1984) - Kočí, p. 98 , fig. 2 .

2012a Placostegus zbyslavus (ZIEGLER) - Kočí, p. 10, pl. 1, fig. 3 .

2012b Placostegus zbyslavus (ZIEGLER) - Kočí, p. 122 -123 , fig. $1 \mathrm{H}$.

Mat e ri a 1: Two complete specimens with the anterior tube portion preserved and two other specimens with the anterior portion damaged.

Substrate: Not preserved.

Description. Tube triangular in cross-section. Attached posterior tube portion planispiral, diameter of spiral at base 3.4-3.7 mm. Free anterior tubeportion rises steeply above substrate, total height $4-5 \mathrm{~mm}$, tube diameter of anterior portion 1.2-1.7 mm. Attached portion has one keel, free portion has three strong but rounded keels. Transverse ornamentation of attached tube portion consists of fine but distinct wrinkles, free tube portion lacks transverse ornamentation. Lumen circular.

Remarks and relationships. Ziegler (1984) described and in part figured several specimens of the present species from different localities. The specimens described as Eoplacostegus dentatus (BRÜNNICH NIELSEN, 1931) by Ziegler (1984) from Předboj (NM-O5388) and from Kaňk (NM-O5387) belong to Placostegus zbyslavus. They correspond with $P$. zbyslavus in the triangular cross-section of the planispiral attached tube portion, and they differ from the specimen from the Danian of Denmark described as “Eoplacostegus (Caesicius) dentatus (NIELSEN, 1931)" by Regenhardt (1961) which has denticulated longitudinal keels. Specimen number NM-O5388 has many borings produced by unknown marine organisms. Its attached portion is triangular in cross-section, and the free portion is circular. The specimen of $P$. zbyslavus NM-O5390 from Zbyslav no. 51 bears transverse ornamentation and has a triangular cross-section.

In addition to these specimens figured by Ziegler (1984), there are some other specimens belonging to P. zbyslavus which were not figured in Ziegler (1984) but, nevertheless, are kept in the collection of his original specimens in the NM Prague. A tube of the present species from Velim-Skalka bears inventory number NM-O5172, the same number had erroneously been mentioned by Ziegler (1984, p. 236) as the number of the holotype of this species, although the figure number 1 is correct (in spite of the wrong plate number, 5 instead of 6) and the correct type locality Zbyslav no. 51 indicate specimen no. NM-O5390 figured on pl. 6, fig. 1 to be the correct holotype. Another unfigured specimen of the present species from Velim has inventory number NM-O5389 which is presumably the correct number, even though Ziegler (1984, p. 253) had erroneously mentioned this number in the figure caption of his so-called "Eoplacostegus sulcatus (SOWERBY, 1829)" from Velim which represents, however, a fine specimen of Laqueoserpula reussi with a rounded quadrangular cross-section and whose correct number, according to the label, is NM-O5167.

Placostegus rigidus (REGENHARDT, 1961) is rather similar in its triangular tube, but has somewhat sharper longitudinal keels. Cycloplacostegus pusillus (J. DE C. SowERBY, 1844) has a circular cross-section, and its surface bears fine granulation.

\section{Placostegus rigidus (REGENHARDT, 1961)}

\author{
Pl. 1, Fig. 9, 10; P1. 3, Fig. 4
}

1961 Eoplacostegus (Eoplacostegus) rigidus n. sp. Regenhardt, p. 61, pl. 5, fig. 4.

1983 Eoplacostegus rigidus REGENHARDT, 1961 Jäger, p. 98-99, pl. 12, fig. 1-3.

2005 Placosteugs rigidus (REGENHARDT, 1961) - Jäger, p. 170.

2012b Placostegus sp. - Kočí, p. 123, fig. 1I-K.

Materia 1: Six specimens in which at least parts of the attached posterior tube portion as well as the free rising anterior tube portion are preserved, one coil, and 21 specimens of which only the free anterior tube portion is preserved.

Substrate: One specimen is attached to an oyster valve Ostrea sp., another specimen is attached to a bryozoan stem. Vice versa, three Placostegus tubes are used as substrates, each of them by a Dorsoserpula bipartita tube.

D e s c ription. The posterior tube portion attached to the substrate is straight or coiled to form a loop, the anterior free tube portion is long and rises steeply. One sharp, sometimes undulating keel is present in the posterior tube portion, three sharp keels in the free tube portion, forming three spines surrounding the aperture of the free tube portion. Between the keels a narrow longitudinal furrow may be present. Apart from the keels and furrows, the surface of the tube appears to be smooth at first sight, but under the microscope very fine distinct transverse corrugations are visible. Cross-section of the tube triangular, subtriangular or, less typical, square.

Remarks and relationships. The tube of Placostegus velimensis JÄGER et KOČí, 2007 is similar in shape, but the present species has a narrower tube diameter, less developed transverse ornamentation, and most tubes are triangular to subtriangular instead of square in cross-section. The tube of Placostegus aduncus (REGENHARDT, 1961) is similar, too, but it differs by its often very well developed transverse ribs. Also Placostegus zbyslavus differs from the present species by its transverse ornamentation and its possibly more often planispirally coiled attached posterior tube portion. 


\section{Placostegus sp.}

$$
\text { P1. 2, Fig. } 10
$$

$2012 \mathrm{c}$

$$
\text { Placostegus sp. - Kočí, p. 126, fig. 1M-N. }
$$

Material: Two small specimens of the attached posterior tube portion; neither the posteriormost part nor aperture are preserved.

Substrate: Both tubes together are attached to one tube of Pyrgopolon (Septenaria) sp.

Description. The tubes are slightly curved or meandering. The diameter increases slowly up to $1 \mathrm{~mm}$. A low narrow but sharp and distinct median keel is present. One of the two tubes has a longitudinal furrow in the lower part of the latera. The transverse ornamentation consists of delicate striae which on the latera are curved forward towards the keel. The tube is subtriangular in cross-section with convex latera especially in the posterior portion. Tubulae can be detected near the damaged area anteriorly though not posteriorly.

Remarks and relationships. Although the small posterior tube portions do not show many special features, comparison with similar posterior and middle portions of more completely preserved unequivocal specimens of the genus Placostegus from Velim and Kaňk makes affiliation also of the present specimens from Předboj to this genus probable. Moreover, it is possible that these specimens are juveniles of one of the other Placostegus species described in the present paper.

\section{Pyrgopolon DE MonTforT, 1808}

\section{Pyrgopolon (Septenaria) cf. tricostata (GoLdFuss, 1841)}

P1. 2, Fig. 8-9; Pl. 4, Fig. 2

1910 Burtinella (?) Reussi m. - Weinzettl, p. 23-24, pl. 3, fig. 48, 50. (NM-O3536)

non 1910 Burtinella (?) Reussi m. - Weinzettl, p. 23-24, pl. 3, fig. 46-47, 49, and 51.

1984 Ditrupa tricostata (GoldFuss), 1841 - Ziegler, p. 239, pl. 6, fig. 8-9. (NM-O5394-5395)

2009a Pyrgopolon cf. tricostata (Goldfuss) - Kočí, p. 98-100, fig. 5-6.

2010 Pyrgopolon (Septenaria) cf. tricostata (GolDFUSS) - Kočí, p. 124-125, fig. 5-6.

2012a Pyrgopolon (Septenaria) cf. tricostata (GoldFuss) - Kočí, p. 10-11, pl. 1, fig. 4a-b.

2012c Pyrgopolon (Septenaria) cf. tricostata (GoldFuss, 1831) - Kočí, p. 126, fig. 1I-L.

Materia 1: At least four specimens. Two incomplete specimens representing the anterior tube portion with the aperture preserved, one of them with remains of the transitional area between the attached and the free portion.

Substrate: Not preserved. One of the tubes is infested by the symbiont Protulophila gestroi Rovereto, 1901.

D e s c r i p tio n. A medium-sized Pyrgopolon. The free tube portion is straight and measures $2.9 \mathrm{~mm}$, respectively $3.4 \mathrm{~mm}$ in diameter which stays nearly constant throughout the whole free tube portion. The upper side of the tube bears three strong straight keels of which the median keel is the strongest and highest. In the lower left and right there are two more keels but these are wide and very rounded, in cross-section appearing like lobes. Faint incremental lines protrude slightly on the median keel and cause this keel to protrude a little over the aperture. Apart from the keels and the faint incremental lines, the tube's surface appears to be relatively smooth. The lumen is circular. The colour is usually brownish.

Remarks and relationships. The tubes from Předboj differ considerably from Pyrgopolon ( $P$. or Triditrupa) tricostata sensu stricto from the Middle Cenomanian of Essen in which the tube diameter increases rapidly in size, it has three wide rounded keels situated at almost equal distances from each other all around the tube, and its circular inner tube wall is visible from the posterior tube fracture. This latter factor is typical for nearly all subgenera of the genus Pyrgopolon except for the subgenus Pyrgopolon (Septenaria) REgENHARDT, 1961, see Jäger (2005). Thus, the tubes from Předboj may even belong to a different subgenus than tricostata sensu stricto.

Moreover, the tubes from Předboj also differ from tubes from Saxony described by Jäger (2014) as "Pyrgopolon (Septenaria) sp. aff. tricostata" in which the keels, in spite of considerable variation, are more similar to those of tricostata sensu stricto.

Within the BCB, except for its Saxon portion, the tubes from Předboj represent a similar fauna as the tubes described by Kočí (2009a, b, 2010, 2012a) from other rocky coast facies localities (Kaňk, Velim, Nová Ves near Kolín, Chrtníky, Kamajka) which display a wider range of tube diameters. For a more detailed discussion see Kočí (2012a).

The two specimens described and figured by Ziegler (1984) as "Ditrupa tricostata (GoldFuss), 1841" may, in spite of some morphological differences, represent the same species as the Předboj tubes. One of these specimens (NM-O5394) possesses a "Favosites structure" at the transition from the attached to the free tube portion; as a consequence at least this specimen belongs to the subgenus Pyrgopolon (Septenaria). Moreover, in the collection of Ziegler's original specimens kept in the National Museum in Prague, there is another but unfigured specimen of $P$. cf. tricostata labelled with inventory number NM-O5363 instead of the missing "Ditrupa subtorquata" specimen with the same registration number figured by Ziegler (1984, pl. 6, fig. 7).

\section{Pyrgopolon (Septenaria) nekvasilovae sp. nov.}

$$
\text { Pl. 2, Fig. 5-7 }
$$

2012c Pyrgopolon (Septenaria) sp. 1 - Kočí, p. 126, fig. $1 \mathrm{E}-\mathrm{H}$.

D i a g n o s i s: A medium-sized species of the subgenus Pyrgopolon (Septenaria). Attached tube portion bears five distinct keels of which the median keel is very strong and undulating, whereas the other four keels are weaker and straight. Free tube portion bears seven moderately to weakly developed keels giving the tube a near-circular subheptagonal cross-section. 
E ty m o logy: In honour of Dr. Olga Nekvasilová, CSc. (the famous Czech specialist in Mesozoic brachipods) who studied the geology and paleontology of the Předboj site and other rocky coast localities in the $\mathrm{BCB}$.

Holotype: The specimen is deposited in the collections of the National Museum in Prague, inventory number NM-O7561, and figured on Pl. 2, Fig. 7.

Type locality: Předboj near Prague.

Type horizon: Upper Cenomanian.

Materia 1: Three well preserved tubes.

$\mathrm{Substrate:}$ One of the tubes is attached to an oyster valve.

D e s c ription. The attached tube portion is slightly to strongly curved posteriorly and straight anteriorly, the short straight free anterior tube portion rises moderately above the substrate. For keels and cross-section see diagnosis. Anterior tube portion bears transverse ornamentation consisting of indistinct weak corrugations.

Remarks and relationships. Pyrgopolon (Septenaria) zitti (see below) is similar, but differs by possessing only three keels situated closer together in the attached tube portion.

Pyrgopolon (Septenaria) septenaria REGENHARDT, 1961 and $P$. (S.) macropus (J. DE C. SowerBY, 1829) possess respectively five and seven keels in the free tube portion, but differ by possessing only one strong keel in the attached portion.

\section{Pyrgopolon (Septenaria) zitti sp. nov.}

$$
\text { Pl. 2, Fig. 1-4; Pl. 3, Fig. } 5
$$

2012c Pyrgopolon sp. 3 - Kočí, p. 126, fig. 1A-C.

2012c Propomatoceros? sp. - Kočí, p. 124-126, fig. 1D.

D i a g n o s is: A moderately large-sized species of the subgenus Pyrgopolon (Septenaria). Attached tube portion has three keels close to each other; the median keel appears as a high and sometimes undulating comb, the other two keels are straight and much smaller. One or two additional rounded longitudinal edges may or may not be present on the latera. No transverse ornamentation. Cross-section triangular.

E ty m o logy: In honour of Dr. Jiří Žítt, CSc. (the famous Czech specialist in Mesozoic echinoids, asteroids and crinoids) who studied the geology and paleontology of the Předboj site and other rocky coast localities in the BCB.

Holotype: The specimen is deposited in the collections of the National Museum in Prague, inventory number NM-O7555, and figured on Pl. 2, Fig. 1, as the holotype. The specimens with inventory numbers NM-O7556, O7557, O7558 and O7571 and figured on Pl. 2, Fig. 2, 3, 4 and Pl. 3, Fig. 5 are paratypes.

Type locality: Předboj near Prague.

Type horizon: Upper Cenomanian.

Materia 1: At least four specimens representing at least 16 tubes, maybe more.

$\mathrm{S}$ ubstrat e: Four tubes are attached to an oyster valve, eight tubes are attached to a Spondylus valve and in part to each other (Pl. 3, Fig. 5), two specimens (Pl. 2, Fig. 3-4) each consist of two tubes of which the upper one is attached to the lower one.

Description. Tube moderately large in size. The attached tube portion has three keels situated close to each other; the median keel is developed as a high and, in some tubes, undulating comb, whereas the other two keels are straight and much smaller, but nevertheless distinct. In a few tubes, one or two additional rounded longitudinal ridges may be present on the latera. Otherwise the surface is rather smooth; no transverse ornamentation. Tube triangular in cross-section; lumen circular. One or two specimens, including one of the two tubes shown in Pl. 2, Fig. 4, possess a distinct "Favosites structure". However, the other tube shown in Pl. 2, Fig. 4 shows in cross-section depressions at the lateral areas of the base which may be interpreted as tubulae. Tube colour is bright yellow, slightly brighter than in Pyrgopolon gen. et sp. indet.

Remarks and relationships. The welldeveloped keels and the lack of peristomes point to the genus Pyrgopolon, and the presence of a distinct "Favosites structure" (Jäger 1983, Jäger and Breton 2002) characteristic for Pyrgopolon (Septenaria) clearly proves affiliation to this subgenus. However the triangular cross-section resembles that of the genera Propomatoceros, Spirobranchus and some fossil specimens of Neovermilia, all of these lacking a "Favosites structure". One of the two tubes in Pl. 2, Fig. 4 shows structures which may be tubulae which are known in the above mentioned genera Propomatoceros, Spirobranchus, Neovermilia and others and in the subgenus Pyrgopolon (Pyrgopolon), but not in the subgenus Pyrgopolon (Septenaria), making determination of this specimen doubtful, even though its well-developed keels clearly match those of Pyrgopolon (Septenaria) zitti.

Pyrgopolon (Septenaria) sp. A1 (Kočí 2010) from the rocky coast facies locality Velim differs in its lower, less prominent median keel, a more rounded cross-section and a thinner tube wall. In Pyrgopolon (Septenaria) sp. A2 (Kočí 2010), also from Velim, the two lateral keels are weakly developed.

\section{Pyrgopolon (Septenaria) sp.}

$$
\text { P1. 2, Fig. } 10
$$

2012c Pyrgopolon (Septenaria) sp. 2 - Kočí, p. 126, fig. $1 \mathrm{M}-\mathrm{N}$.

Materia l: One fragment of the posterior tube portion.

$\mathrm{Substrate:}$ The former substrate of this Pyrgopolon tube is unknown, but in turn the Pyrgopolon tube was used as a substrate for two juvenile serpulid tubes described above as Placostegus sp.

Description. The formerly attached tube portion is $6.4 \mathrm{~mm}$ wide (measured at the base) and $5 \mathrm{~mm}$ high. It bears five straight strong but rounded keels, of which the median one is the strongest and widest, two are in an upper/lateral position and two are in a lower lateral position, situated slightly above the tube's base. Otherwise the tube's surface is smooth. 
Remarks and relationships. The wide and rounded median keel resembles that of Pyrgopolon subgen. et sp. indet., but the chevron pattern is not developed or not well developed, and the other keels are more distinctly developed.

\section{Pyrgopolon subgen. et sp. indet.}

$$
\text { Pl. 2, Fig. 11-12 }
$$

2012c Pyrgopolon (Septenaria)? Pyrgopolon (Pyrgopolon) subsp. [sic!] indet. - Kočí, p. 126-127, fig. 1O-Q.

\section{M a t e ri a 1: Two large tubes.}

$\mathrm{Substrate}$ : The tubes had previously been attached to an unknown substrate.

Description. Tube large, 5.5-7.4 mm wide (measured at the base) and 5.8-6.0 $\mathrm{mm}$ high at the aperture respectively at the anterior cross-section; length reaching more than $25 \mathrm{~mm}$ in the longest preserved fragment. Attached posterior portion slightly twisted to strongly curved, free anterior portion unknown if at all existing. The attached portion in some specimens bears three keels or rounded edges, in other specimens five, most of them are inconspicuous except for the very broad flat median keel which shows a distinct chevron-like or V-like pattern of strongly protruding incremental lines. Cross-section rounded triangular posteriorly but tunnel-shaped or rounded trapezoid anteriorly. Lumen circular. Tube wall thick, with a thin innermost tube layer which is slightly separated from the main tube layer.

Remarks and relationships. In the Late Cretaceous of Europe the vast majority of Pyrgopolon specimens belong to one of two subgenera, P. (Pyrgopolon) and $P$. (Septenaria), which may look more or less similar in outer aspect but are usually well distinguishable by several features of the tube structure: usually P. (Pyrgopolon) has a moderate to thin tube wall and well-developed chambered tubulae in the lateral areas of the attached tube base, and often its inner tube layer is more or less separated from the outer tube layer during diagenesis. In contrast, $P$. (Septenaria) has a moderate to thick tube wall, which in the lower half of the attached portion may show "Favosites structure" which is a cellular structure resembling that of the Paleozoic coral genus, and some specimens may show a honeycomb-like ornamentation on the surface of the tube.

The problem with the present species is that it combines features of both previously mentioned subgenera, and plus the low number of available specimens mean it is therefore impossible to affiliate it to any subgenus at the present state of knowledge. Features pointing to $P$. (Pyrgopolon) are a thin innermost tube layer which is slightly separated from the main tube layer and the nondevelopment of a "Favosites structure" (Jäger 1983, Jäger and Breton 2002) and honeycomb-like ornamentation. Features pointing to $P$. (Septenaria) are the thick tube wall and the absence of tubulae.

In its relatively large size and thick tube wall, the present species resembles Pyrgopolon (Septenaria) sp. B (Kočí 2010) which, however, has a thicker external tube layer and developed cellular layers.

\section{Subfamily Spirorbinae ChamberLin, 1919}

\section{Neomicrorbis ROVERETO, 1903}

Affiliation of this genus to either Spirorbinae or nonspirorbin Serpulidae is still debated (see Ippolitov et al. 2014).

\section{Neomicrorbis crenatostriatus subrugosus (MÜNSTER in GOLdFUSS, 1831)}

$$
\text { P1. 3, Fig. } 1
$$

1831 Serpula subrugosa MüNSTER - Goldfuss, p. 239, pl. 71, fig. 1a-b.

1983 Neomicrorbis subrugosus (MÜNSTER in GOLDFUSS, 1831) - Jäger, p. 127-128, pl. 15, fig. 9-11.

2005 Neomicrorbis crenatostriatus subrugosus (MÜNSTER in GolDFuss, 1831) - Jäger, p. 197, pl. 9, fig. 11.

2012b Neomicrorbis crenatostriatus subrugosus (MÜNSTER in GoldFuss, 1831) - Kočí, p. 123, fig. 1N.

Materia l: Two tubes.

S ubstrate: Both tubes are attached to a dorsal valve of the brachiopod Cyclothyris aff. difformis (VALENCIENNES in LAMARCK, 1819).

D e s c ription. The tube is circular, smooth, sinistrally coiled. Spiral diameter is $0.5-1.1 \mathrm{~mm}$.

Remarks and relationships. Due to their small sizes, the present specimens are certainly juveniles. Detailed remarks and relationships of $N$. c. subrugosus are mentioned in Sklenář et al. (2013).

\section{Bipygmaeus REGENHARDT, 1961}

\section{Bipygmaeus pygmaeus (VON HAGENOW, 1840)}

1840 Serpula pygmaea nob. - von Hagenow, p. 667.

1961 Spirorbis (Bipygmaeus) pygmaeus (HAGENow, 1840) - Regenhardt, p. 89.

1983 Bipygmaeus pygmaeus (HAGENOw, 1840) - Jäger, p. 132-133, pl. 16, fig. 13-15.

Materia 1: Two damaged specimens of which at least one could belong to the present species.

$\mathrm{S}$ u b s trat e: Both tubes are attached to a serpulid tube of the genus Pyrgopolon.

No description is given here due to insufficient preservation.

\section{Palaeoecological remarks - worms and their substrates}

The worm-substrate relationship has been at least a partial subject of many papers dealing with polychaetes (e.g. Taylor and Wilson 2003, Žítt et al. 2003, Sørensen and Surlyk 2010) among other benthic organisms since the 1960s. An exhaustive study of soft-bottom dwellers was published by Seilacher et al. (2008). The substrate preferences or the life strategies of taxa present at the locality Předboj are summarized below. Identified substrates inhabited by sabellids and serpulids at Předboj are also mentioned by us in the chapters on the individual species. 
Larvae of the sabellid species Glomerula serpentina attached themselves not only to bivalve shells (see above), but frequently also to tiny substrates such as small shell fragments, large foraminifers or sand grains. During growth, a self-supporting knot-like reeflet ("glomerate knot") adapted for living on soft bottom is produced (Seilacher et al. 2008).

In accordance with the vast majority of extant serpulid species, all serpulid species found at Předboj are obligate encrusters. Some of the Předboj serpulids, especially Pyrgopolon (Septenaria) zitti, but also Cementula sp. and Laqueoserpula reussi, built small clusters consisting of two tubes, rarely more, in which one tube was attached to another tube of the same species. Moreover, there are several specimens in which one serpulid tube is attached to the tube of a different serpulid species. For example, three specimens of Dorsoserpula bipartita are each attached to a separate tube of Placostegus rigidus, and two tubes of Placostegus sp. are attached to a single tube of Pyrgopolon (Septenaria) sp.

The Předboj serpulids are not specialized for any specific kind of hard substrate. Medium-sized to relatively large oyster valves and other bivalve shells are among the most common substrates onto which serpulids have settled. Dense spatfall had perhaps been the reason for the crowding of eight tubes of Pyrgopolon (Septenaria) zitti densely attached to a Spondylus valve and to each other (Pl. 3, Fig. 5).

Three brachiopod shells had been settled on by serpulid tubes. Two of these three specimens have a D. bipartita tube attached to the dorsal valve of Phaseolina phaseolina; one of these two tubes is oriented with its aperture towards the anterior commissure (Pl. 3, Fig. 2), the other towards the lateral commissure. The third specimen has two tubes of Neomicrorbis crenatostriatus subrugosus on the dorsal valve of Cyclothyris aff. difformis, between the ribs near the anterior commissure. These tubes attached close to the commissures of brachiopod shells could have fed upon microscopical food particles which were transported by currents produced by the activity of the brachiopods' lophophorate apparatus (P1. 3, Fig. 1) - provided that the brachiopods were still alive which is, however, unknown.

As is common in the genus Dorsoserpula, some but not all tubes of $D$. bipartita coiled spirally around a longer present upright cylindrical object which may had been the stem of an alga, another serpulid tube, or a crinoid stem. Crinoid columnals have been found in the centre of $D$. bipartita coils at other rocky coast facies sites of the BCB, e.g. Velim, Kamajka, and Chrtníky, as well as in the centre of D. wegneri wegneri at Úpohlavy (Sklenár et al. 2013) and in northern Germany (Jäger 1983).

Vice versa, serpulid tubes had often been settled on by other organisms. Some tubes, especially some specimens belonging to different species of the genera Pyrgopolon (e.g. P1. 2, Fig. 1, 10, 12; P1. 4, Fig. 2) and Neovermilia (P1. 4, Fig. $1)$, show variable numbers of small holes. While these small holes are true borings by some unknown organisms into a formerly intact serpulid tube wall, additonal larger holes in one of these serpulid tubes (Pl. 4, Fig. 2), some of a more oval shape and surrounded by a small elevated rim, were produced by the serpulid itself when prolonging its tube and thereby surrounding stolons of the symbiotic hydroid Protulophila gestroi Rovereto, 1901 living inside the serpulid tube wall (see e.g. Zágoršek et al. 2009).

The common and diverse occurrence of medium- to large-sized and relatively thick-walled tubes of the subgenus Pyrgopolon (Septenaria) points to adaptation to an environment of high water energy. Some of the relatively smaller-sized serpulids, e.g. the Dorsoserpula tubes coiling around vertical substrates and the Dorsoserpula and Neomicrorbis tubes settling on the valves of living(?) brachiopods, may also have been exposed to considerable water energy, whereas other smaller-sized serpulids, e.g. Filogranula, Cementula and others, may alternatively have settled on bioclasts or rocks within small cryptic environments of lower water energy.

\section{Conclusions}

A diverse tube-dwelling polychaete fauna thrived in the rocky coast environments near Předboj, comprising 10 genera and 16 species, some of them described in open nomenclature.

Two new species, Pyrgopolon (Septenaria) nekvasilovae sp. nov. and Pyrgopolon (Septenaria) zitti sp. nov., are described.

The relatively high diversity of tube dwelling polychaetes - sabellids and serpulids including spirorbins - is not unusual, and similar assemblages are known especially from other Late Cenomanian and Early Turonian shallow marine rocky coast sites in the Bohemian Cretaceous Basin, e.g. Velim, Kaňk, Kamajka, Chrtníky, and Zbyslav (Ziegler 1984, Kočí 2009a, 2010, 2012a, Žítt and Nekvasilová 1996, Žítt et al. 2006). Moreover, the fauna resembles that of shallow marine sites in northwest Germany, northeast Belgium, southeast Netherlands, southeast France and southern Sweden (Jäger 1983, 2005, 2012, Sørensen and Surlyk 2010).

The common and diverse occurrence of medium to large sized and relatively thick-walled tubes of the subgenus Pyrgopolon (Septenaria) points to adaptation to a high water energy environment. Also the Dorsoserpula tubes coiled around vertical substrates and the Dorsoserpula and Neomicrorbis tubes settled on the valves of living(?) brachiopods may also have been exposed to considerable water energy, whereas other smaller-sized serpulids may alternatively have settled on bioclasts or rocks within small cryptic environments of lower water energy.

\section{Acknowledgements}

We greatly thank Dr. Olga Nekvasilová for her thorough collecting at the classical locality of Předboj which is no longer accessible. We are greatly indebted to Jan Sklenář, Ph.D. of the National Museum in Prague for loan of all the material from Dr. Olga Nekvasilová's collection for the present study and for his assistance and good advice for improving the plates. We greatly thank the reviewers Dr. Olev Vinn, PhD. (University of Tartu), RNDr. Jiří Žítt, CSc. (Institute of Geology of the Czech Academy Sciences) and Jan Wagner, Ph.D. (National Museum and Institute of Geology of the Czech Academy Sciences) for their helpful comments which 
improved the manuscript. We greatly thank Gill Horalek for her helpful improvement of our English which improved the manuscript. T. K. thanks Associate Prof. Václav Ziegler for providing material from this locality which was collected by Dr. Olga Nekvasilová, CSc. in 1962, and Mgr. Martina Kočová Veselská and Mgr. Martina Nohejlová for their help with photography. The research was financially supported by Ministry of Culture of the Czech Republic (DKRVO 2015/06, National Museum, 00023272).

\section{References}

Backhaus, E. (1959): Monographie der cretacischen Thecideidae (Brachiopoda). - Mitteilungen aus dem geologischen Staatsinstitut in Hamburg, 28: 5-90.

Benedict, J. E. (1887): Descriptions of ten species and one new genus of annelids from the dredgings of the U.S. Fish Commission Steamer Albatross. - Proceedings of the United States National Museum, 9: 547-553. http://dx.doi.org/10.5479/si.00963801.9-594.547

Blainville, H. de (1818): Mémoire sur la classe des Sétipodes, partie des Vers à sang rouge de $\mathrm{M}$. Cuvier, et des Annélides de M. de Lamarck. - Bulletin des Sciences, par la Société Philomatique de Paris, 1818: 78-85.

Blainville, H. M. D. de (1825-1827): Manuel de malacologie et de conchyliologie. - Levrault, Paris and Strasbourg, 664 pp. (1825), 87 pls (1827).

Brünnich Nielsen, K. (1931): Serpulidae from the Senonian and Danian deposits of Denmark. - Meddelelser fra Dansk geologisk Forening, 8: 71-113.

Chamberlin, R. V. (1919): The Annelida Polychaeta of the Albatross Tropical Pacific Expedition, 1891-1905. Memoirs of the Museum of Comparative Zoology, Harvard University, 48: 1-514.

Day, J. H. (1961): The polychaete fauna of South Africa, 6. Sedentary species dredged off Cape coasts with a few new records from the shore. - Journal of the Linnean Society of London, Zoology, 44(299): 463-560.

Defrance, M. (1827): Serpule. - In: Levrault, F. G. (ed.), Dictionnaire des sciences naturelles, vol. 48., F. G. Levrault, Le Normant, Strasbourg, Paris, p. 549-572.

Dew, B. (1959): Serpulidae (Polychaeta) from Australia. Records of the Australian Museum, 25(2): 19-56. http://dx.doi.org/10.3853/j.0067-1975.25.1959.654

Fauchald, K. (1977): The Polychaete worms. Definitions and keys to the orders, families and genera. - Natural History Museum of Los Angeles County, Science Series, 28: $1-190$

Frič, A. (1911a): Studien im Gebiete der Böhmischen Kreideformation. Palaeontologische Untersuchungen der einzelnen Schichten. Ergänzung zu Band 1. Illustriertes Verzeichniss der Petrefacten der cenomanen Korycaner Schichten. - Archiv für die naturwissenschaftliche Landesdurchforschung von Böhmen, 15(1): 1-101.

Frič, A. (1911b): Studie v oboru českého útvaru křídového. Paleontologický výzkum jednotlivých vrstev. Doplněk k 1. dílu Archivu I., Sekce II. Illustrovaný seznam zkamenělin cenomanních vrstev korycanských [Research in Bohemian Cretaceous formation. Palaeontological investigation of particular layers. Addendum to the $1^{\text {st }}$ part of Archiv I., Section II. Illustrated list of Cenomannian fossils from Korycany layers]. - Archiv pro přírodovědecký výzkum Čech, 15(1): 1-101. (in Czech)

Geinitz, H. B. (1875): Vermes. Würmer. - In: Geinitz, H. B. (1871-1875): Das Elbthalgebirge in Sachsen. Erster Theil. Der untere Quader. Palaeontographica, 20(1): 282-287, pl. 63-64.

Goldfuss, A. (1826-1844): Petrefacta Germaniae: tam ea quae in Museo Universitatis Regiae Borussicae Fridericiae Wilhelmiae Rhenanae servantur quam alia quaecunque in Museis Hoeninghusiano Muensteriano aliisque extant; iconibus et descriptionibus illustrata. Abbildungen und Beschreibungen der Petrefacten Deutschlands und der angränzenden Länder, unter Mitwirkung des Herrn Grafen Georg zu Münster, herausgegeben von August Goldfus[s]. - Arnz \& Co., Düsseldorf, 1 (1): i-viii + 1-76, pl. 1-25 (1826); 1 (2): 77-164, pl. 26-50 (1829); 1 (3): 165-240, pl. 51-71 (1831); 1 (4): 241-252 (1833); 2 (1): 1-68, pl. 72-96 (1834); 2 (2): 69-140, pl. 97-121 (1835); 2 (3): 141-224, pl. 122-146 (1837); 2 (4): i-iii + 225-312, pl. 147-165 (1840); 3 (1): 1-20, pl. 166-171 (1841); 3 (2): 21-28, pl. 172-195 (1844); 3 (3): i-iv + 29-128, pl. 196-200 (1844).

Grube, A. E. (1850): Die Familien der Anneliden. - Archiv für Naturgeschichte, 16: 249-364.

Hagenow, F. von (1840): Monographie der Rügen'schen Kreide-Versteinerungen, 2, Radiarien und Annulaten. Neues Jahrbuch für Mineralogie, Geognosie, Geologie und Petrefakten-Kunde, 1840: 631-672.

Hedley, R. H. (1958): Tube formation by Pomatoceros triqueter (Polychaeta). - Journal of the Marine Biological Association of the United Kingdom, 37: 315-322. http://dx.doi.org/10.1017/S0025315400023717

Hove, H. A. ten, Jansen-Jacobs, M. J. (1984): A revision of the genus Crucigera (Polychaeta; Serpulidae); a proposed methodical approach to serpulids, with special reference to variation in Serpula and Hydroides. - In: Hutchings, P. A. (ed.), Proceedings of the First International Polychaete Conference, Sydney, Australia, July 1983, The Linnean Society of New South Wales, Sydney, p. 143-180.

Hove, H. A. ten, Kupriyanova, E. K. (2009): Taxonomy of Serpulidae (Annelida, Polychaeta): The state of affairs. Zootaxa, 2036: 1-126.

Ippolitov, A. P., Vinn, O., Kupriyanova, E. K., Jäger, M. (2014): Written in stone: history of serpulid polychaetes through time. - Memoirs of Museum Victoria, 71: 123-159.

Jäger, M. (1983): Serpulidae (Polychaeta sedentaria) aus der norddeutschen höheren Oberkreide - Systematik, Stratigraphie, Ökologie. - Geologisches Jahrbuch, Reihe A, 68: 3-219.

Jäger, M. (2005): Serpulidae und Spirorbidae (Polychaeta sedentaria) aus Campan und Maastricht von Norddeutschland, den Niederlanden, Belgien und angrenzenden Gebieten. - Geologisches Jahrbuch, Reihe A, 157(2004): 121-249.

Jäger, M. (2011): Sabellidae, Serpulidae and Spirorbinae (Polychaeta sedentaria) from the Barremian (Lower Cretaceous) of the Serre de Bleyton (Drôme, SE France). - Annalen des Naturhistorischen Museums in Wien, Serie A, 113: 675-733.

Jäger, M. (2012): Sabellids and serpulids (Polychaeta sedentaria) from the type Maastrichtian, the Netherlands and Belgium. - In: Jagt, J. W. M., Donovan, S. K., Jagt- 
Yazykova, E. A. (eds), Fossils of the type Maastrichtian (Part 1). Scripta Geologica, Special Issue, 8: 45-81.

Jäger, M. (2014): 4. Serpuliden und Sabelliden. Serpulids and sabellids. - In: Niebuhr, B., Wilmsen, M. (eds), KreideFossilien in Sachsen, Teil 1. Cretaceous fossils of Saxony, part 1. Geologica Saxonica, 60(1): 57-81.

Jäger, M., Breton, G. (2002): Un tube géant de Serpulide, Pyrgopolon (Septenaria) marechali n. sp. (Polychaeta) du Cénomanien inférieur (Crétacé supérieur) du Cap de la Hève (Normandie, France). - Bulletin trimestriel de la Société géologique de Normandie et des Amis du Muséum du Havre, 87(4): 39-45.

Jäger, M., Kočí, T. (2007): A new serpulid, Placostegus velimensis sp. nov., from the Lower Turonian of the Bohemian Cretaceous Basin. - Acta Geologica Polonica, 57(1), 89-96.

Klein, V. (1952): Předběžná zpráva o výzkumu cenomanu a spodního turonu $\mathrm{v}$ prríbojové facii mezi Kladnem a Brandýsem nad Labem [Preliminary report on research on the Cenomanian and Lower Turonian in rocky coast facies between Kladno and Brandýs nad Labem]. Věstník Ústředního ústavu geologického, 27: 155-157. (in Czech)

Kočí, T. (2007a): Nové nálezy serpulidních červů z lokality Velim-Skalka [New occurrence of serpulid worms from locality at Velim-Skalka in Bohemian Cretaceous Basin]. - Zprávy o geologických výzkumech v roce 2006, 40: 109-111. (in Czech with English summary)

Kočí, T. (2007b): První výskyt serpulidního červa druhu Filogranula cincta (Goldfuss) v prríbojové facii České krrídové pánve [First occurrence of serpulid worm Filogranula cincta (Goldfuss) in Cretaceous sediments in Bohemia]. - Zprávy a geologických výzkumech v roce 2006, 40: 112-113. (in Czech with English summary)

Kočí, T. (2009a): Nové nálezy serpulidních červů (Serpulidae) z lokality Kaňk - Na Vrších u Kutné Hory [New finds of serpulid worms from locality [sic!] Kaňk - Na Vrších near Kutná Hora in Bohemian Cretaceous Basin]. - Zprávy o geologických výzkumech v roce 2008, 42: 97-100. (in Czech with English summary).

Kočí, T. (2009b): Nové nálezy a předběžná zpráva o revizi serpulidních červů (Polychaeta, Canalipalpata) z lokalit Velim a Kaňk - Na Vrších (př́ibojová facie české křídové pánve) [New finds and preliminary reports of the revision of serpulid worms (Polychaeta, Canalipalpata) from localities Velim and Kaňk - Na Vrších, Czech Republic (nearshore facies of the Bohemian Cretaceous Basin)]. Vlastivědný zpravodaj Polabí, 39(2007-2008): 207-238. (in Czech)

Kočí, T. (2010): The subgenus Septenaria Regenhardt, 1961 (Polychaeta: Serpulidae) from Lower Turonian (Upper Cretaceous) nearshore facies of the Bohemian Cretaceous Basin, Czech Republic. - Journal of the National Museum (Prague), Natural History Series, 179(10): $119-126$.

Kočí, T. (2011): Sabellid and serpulid worms (Polychaeta, Canalipalpata, Sabellida, Sabellidae, Serpulidae) from nearshore facies locality Předboj near Prague in collections of National Museum at Prague (collections of Dr. Olga Nekvasilová from 1960-1967). - In: Boorová, D. (ed.), 12. Paleontologická konference - zborník príspevkov, October $20^{\text {th }}-21^{\text {th }} 2011$, Bratislava, Slovakia, p. 56-57.

Kočí, T. (2012a): Sabellidae and Serpulidae (Polychaeta, Canalipalpata) from the locality Kaňk - Na Vrších in Kutná Hora (Upper Cenomanian - Lower Turonian, Bohemian Cretaceous Basin - the Czech Republic). Acta Musei Nationalis Pragae, Series B, Historia Naturalis, 68(1-2): 7-14.

Kočí, T. (2012b): Serpulidní červi z lokality př́bojové facie mořského cenomanu Předboj u Prahy ze sbírky Dr. Olgy Nekvasilové - část I [Serpulid worms from rocky coast facies marine Cenomanian Předboj near Prague from the collection of Dr. Olga Nekvasilová - part I] - Zprávy o geologických výzkumech v roce 2011, 45: 120-123. (in Czech with English summary)

Kočí, T. (2012c): Serpulidní červi z lokality příbojové facie mořského cenomanu Předboj u Prahy ze sbírky Dr. Olgy Nekvasilové - část II [Serpulid worms from rocky coast facies marine Cenomanian Předboj near Prague from the collection of Dr. Olga Nekvasilová- part II] - Zprávy o geologických výzkumech v roce 2011, 45: 124-127. (in Czech with English summary)

Lamarck, J.-B. de (1819): Histoire naturelle des animaux sans vertèbres, 6 (1), suite des Conchifères; les Mollusques. - [l'Auteur], Paris, vi + 343 pp.

Langerhans, P. (1884): Die Wurmfauna von Madeira, 4. Zeitschrift für wissenschaftliche Zoologie, 40(2): 247-285.

Latreille, P. A. (1825): Familles naturelles du règne animal, exposé succinctement et dans un ordre analytique avec l'indication de leurs genres. - J. B. Baillière, Paris, 570 pp.

Lommerzheim, A. (1979): Monographische Bearbeitung der Serpulidae (Polychaeta sedentaria) aus dem Cenoman (Oberkreide) am Südwestrand des Münsterländer Beckens. - Decheniana, 132: 110-195.

Montfort, D. de (1808): Conchyliologie systématique et classification méthodique des coquilles, 1. Coquilles univalves, cloisonées. - F. Schoell, Paris, lxxxvii +409 pp., 100 figs.

Nekvasilová, O. (1964): Thecideidae (Brachiopoda) der böhmischen Kreide. - Sborník geologických věd, Paleontologie, 3: 119-162.

Nekvasilová, O. (1967): Thecidiopsis (Thecidiopsis) bohemica imperfecta n. subsp. (Brachiopoda) from the Upper Cretaceous of Bohemia. - Sborník geologických věd, Paleontologie, 9: 115-136.

Nekvasilová, O. (1993): Nové poznatky o terebratulidních brachiopodech z české křídové pánve [New information on the terebratulid brachiopods from the Bohemian Cretaceous Basin]. - Zprávy o geologických výzkumech $\mathrm{v}$ roce 1991, 25: 98-100. (in Czech with English summary)

Nekvasilová, O., Prokop, R. (1963): Roveacrinidae (Crinoidea) from the Upper Cretaceous of Bohemia. Věstník Ústředního ústavu geologického, 3: 49-52.

Parsch, K. O. A. (1956): Die Serpuliden-Fauna des südwestdeutschen Jura. - Palaeontographica, Reihe A, 107: 211-240.

Philippi, A. (1844): Einige Bemerkungen über die Gattung Serpula, nebst Aufzählung der von mir im Mittelmeer mit dem Thier beobachteten Arten. - Archiv für Naturgeschichte, 10(1): 186-198. 
Pillai, T. G. (1993): A review of some Cretaceous and Tertiary serpulid polychaetes of the genera Cementula and Spiraserpula Regenhardt 1961, Laqueoserpula Lommerzheim 1979 and Protectoconorca Jäger 1983. Paläontologische Zeitschrift, 67(1-2): 69-88. http://dx.doi.org/10.1007/BF02985871

Pillai, T. G., Hove, H. A. ten (1994): On Recent species of Spiraserpula Regenhardt, 1961, a serpulid polychaete genus hitherto known only from Cretaceous and Tertiary fossils. - Bulletin of the Natural History Museum London, Zoology, 60(1): 39-104.

Prantl, F. (1929): Příspěvěk k poznání rodu „Lichenopora“ Defr. [Contribution to knowledge of genus Lichenopora Defr.]. - Věstník Státního geologického ústavu Československé republiky, 5: 247-253. (in Czech)

Prantl, F. (1938): Spodnoturonské mechovky z Předboje (Čechy) [Lower Turonian bryozoa from Předboj (Bohemia)]. - Rozpravy Státního geologického ústavu Československé republiky, 8: 1-71. (in Czech)

Radwańska, U. (1996): Tube-dwelling polychaetes from some Upper Cretaceous sequences of Poland. - Acta Geologica Polonica, 46(1-2): 61-80.

Rafinesque, C. S. (1815): Analyse de la nature ou tableau de l'univers et des corps organisés. - [l'Auteur], Palerme, 224 pp.

Regenhardt, H. (1961): Serpulidae (Polychaeta sedentaria) aus der Kreide Mitteleuropas, ihre ökologische, taxonomische und stratigraphische Bewertung. - Mitteilungen aus dem geologischen Staatsinstitut in Hamburg, 30: 5-115.

Reuss, A. E. (1844): Geognostische Skizzen aus Böhmen. 2. Die Kreidegebilde des westlichen Böhmens, ein monographischer Versuch. Nebst Bemerkungen über die Braunkohlenlager jenseits der Elbe und eine Übersicht der fossilen Fischreste Böhmens. - Medau, Prag, vi + 304 pp., 3 pls.

Reuss, A. E. (1845): Die Versteinerungen der böhmischen Kreide-Formation. Mit Abbildungen der neuen oder weniger bekannten Arten. Erste Abtheilung. Schweizerbart, Stuttgart, iv +58 pp., 13 pls.

Reuss, A. E. (1846): Die Versteinerungen der böhmischen Kreide-Formation. Mit Abbildungen der neuen oder weniger bekannten Arten. Zweite Abtheilung. Schweizerbart, Stuttgart, iv + 148 pp., pl. 14-51.

Roemer, F. A. (1840-1841): Die Versteinerungen des norddeutschen Kreidegebirges. - Hahn, Hannover, iv + 145 pp., 2 tbls., 16 pls.

Roule, L. (1898): Notice preliminaire sur les especes d'annélides recueillies dans les explorations sous-marines du „Travailleur“ et du „Talisman“. - Bulletin du Muséum National d'Histoire naturelle de Paris, 4: 190-195.

Rouse, G. W., Fauchald, K. (1997): Cladistics and polychaetes. - Zoologica Scripta, 26(2): 139-204. http://dx.doi.org/10.1111/j.1463-6409.1997.tb00412.x

Rovereto, G. (1901): Briozoi, anellidi e spugne perforanti del Neogene Ligure [Broyzoans, anellids, and boring sponge from the Neogene of Ligure]. - Palaeontographia Italica, 7: 219-234. (in Italian)

Rovereto, G. (1903): Anellidi del terziario [Tertiary anellids]. - Rivista Italiana di Paleontologia, 9(4): 103-104. (in Italian)
Saint-Joseph, A. de (1894): Les Annélides Polychètes des côtes de Dinard. Troisième partie. - Annales des Sciences naturelles, Paris, 7. Serié, 17: 1-395.

Schlotheim, E. F. von (1820): Die Petrefactenkunde auf ihrem jetzigen Standpunkte. - Becker, Gotha, 1xii +437 pp., 29 pls.

Seilacher, A., Olivero, E. B., Butts, S. H., Jäger, M. (2008): Soft-bottom tubeworms: from irregular to programmed shell growth. - Lethaia, 41: 349-365. http://dx.doi.org/10.1111/j.1502-3931.2008.00092.x

Sklenář, J., Kočí, T., Jäger, M. (2013): Late Turonian polychaete communities recorded in the hemipelagic sediments of Bohemian Cretaceous Basin (Teplice Formation, Ohře and Dresden districts). - Bulletin of Geosciences, 88(3): 675-695.

http://dx.doi.org/10.3140/bull.geosci.1412

Sørensen, A. M., Surlyk, F. (2010): Palaeoecology of tube-dwelling polychaetes on a Late Cretaceous rocky shore, Ivö Klack (Skåne, southern Sweden). - Cretaceous Research, 31(6): 553-566. http://dx.doi.org/10.1016/j.cretres.2010.07.005

Sowerby, J. de C. (1829): The mineral conchology of Great Britain, vol. 6. - [The author], London, 230 pp., pl. 506-609.

Sowerby, J. de C. (1840-1846): The mineral conchology of Great Britain, vol. 7. - [The author], London, $80+11$ pp., pl. 610-648.

Svoboda, P. (1982): Srovnání nálezů svrchnocenomanské fauny z Odolena Vody s podobnými lokalitami středních Čech [Comparision of Late Cenomanian fauna from Odolena Voda locality with the faunal record from similar localities in Central Bohemia]. - Bohemia Centralis, 11: 159-164. (in Czech)

Svoboda, P. (1984): Svrchní kř́ida mezi Odolenou Vodou a Neratovicemi-Biškovicemi [Late Cretaceous between Odolena Voda and Neratovice-Biškovice]. - Studie a Zprávy Okresního muzea Praha-východ, 1983-1984: 36-44. (in Czech)

Taylor, P. D., Wilson, M. A. (2003): Palaeoecology and evolution of marine hard substrate communities. - Earth Science Reviews, 62(1): 1-103. http://dx.doi.org/10.1016/S0012-8252(02)00131-9

Thomas, J. G. (1940): Pomatoceros, Sabella, and Amphitrite. - Memoirs of the Liverpool marine Biology Committee, 33: $1-88$.

Vinn, O., Wilson, M. A. (2010): Sabellid-dominated shallow water calcareous polychaete tubeworm association from the equatorial Tethys Ocean (Matmor Formation, Middle Jurassic, Israel). - Neues Jahrbuch für Geologie und Paläontologie, Abhandlungen, 258(1): 31-38. http://dx.doi.org/10.1127/0077-7749/2010/0080

Voigt, E. (1989): Beitrag zur Bryozoen-Fauna des sächsischen Cenomaniums. Revision von A. E. Reuss „Die Bryozoen des unteren Quaders“ in H. B. Geinitz „Das Elbthalgebirge in Sachsen“ (1872). 1. Teil: Cheilostomata. - Abhandlungen des Staatlichen Museums für Mineralogie und Geologie zu Dresden, 36: 8-87.

Ware, S. (1975): British Lower Greensand Serpulidae. Paleontology, 18(1): 93-116.

Weinzettl, V. (1910): Gastropoda českého křídového útvaru [Gastropods of the Bohemian Cretaceous]. - Palaeontographica Bohemia, 8: 1-56. (in Czech) 
Zágoršek, K., Taylor, P. D., Vodrážka, R. (2009): Coexistence of symbiotic hydroids (Protulophila) on serpulids and bryozoans in a cryptic habitat at Chrtníky (lower Turonian, Czech Republic). - Bulletin of Geosciences, 84(4): 631-636.

http://dx.doi.org/10.3140/bull.geosci.1079

Záruba, B. (1998): Zpráva o výskytu nového druhu fosilní ústřice $\mathrm{v}$ české křídě [Report on the occurrence of a new species of fossil oyster in the Czech Cretaceous]. Zprávy o geologických výzkumech v roce 1997, 31: 113-114.

Zázvorka, V. (1939): Spodnoturonská příbojová facie u Předboje (sev. od Prahy) [Early Turonian rocky coast facies near Předboj (north of Prague)]. - Věda Přírodní, 19: 122-124. (in Czech)

Zázvorka, V. (1944a): Spodnoturonská př́bojová facie v Netřebech u Kladna [Early Turonian rocky coast facies in Netřeby near Kladno]. - Věda Přírodní, 22: 51-53. (in Czech)

Zázvorka, V. (1944b): Cenoman a spodní turon u Velkých Př́lep (severně od osady Černý Vůl; sz. od Prahy) [Cenomanian and Early Turonian near Velké Př́lepy (North of Černý Vůl vicinity; N-E from Prague)]. - Věda Přírodní, 22: 141-144. (in Czech)

Zibrowius, H. (1968): Étude morphologique, systématique et écologique des Serpulidae (Annelida Polychaeta) de la région de Marseille. - Recueil des Travaux de la Station Marine d'Endoume, Bulletin, 43(59): 81-252.

Zibrowius, H., Hove, H. A. ten (1987): Neovermilia falcigera (Roule, 1898) a deep- and cold-water serpulid polychaete common in the Mediterranean Plio-Pleistocene. Bulletin of the Biological Society of Washington, 7: 259-271.

Ziegler, V. (1967): Hromadný výskyt druhu Ditrupa tricostata (Goldfuss), 1841 v novoveském lomu u Kolína [Occurrence of species Ditrupa tricostata (Goldfuss), 1841 in the quarry Nová Ves near Kolín]. - Vlastivědný zpravodaj Polabí, 1967(1-2): 14-18. (in Czech)

Ziegler, V. (1974): Serpula ampullacea Sowerby, 1829 (Serpulidae, Polchaeta [sic!], Sedentaria) v České křídě [Serpula ampullacea Sowerby, 1829 (Serpulidae, Polychaeta, Sedentaria) in Bohemian Cretaceous]. - Acta Musei Reginaehradecensis, A: Scientiae naturales, 15: 61-64. (in Czech)

Ziegler, V. (1978): The significance of the family Serpulidae (Polychaeta, Sedentarida [sic!]) for stratigraphic correlation of the Bohemian Cretaceous Basin. - In: Pokorný, V. (ed.), sborník přednášek [abstracts], Paleontologická konference katedry paleontologie na př́rodovědeoké fakultě Univerzity Karlovy, Praha. [Paleontological conference of Department of Paleontology, Faculty of Sciences, Charles University, Prague], February $10^{\text {th }}-11^{\text {th }} 1977$, p. 217-222, pl. 50.

Ziegler, V. (1984): Family Serpulidae (Polychaeta, Sedentaria) from the Bohemian Cretaceous Basin. Sborník Národního muzea v Praze, B, 39(1983)(4): 213-254.

Žítt, J. (1993): Regulární ježovky lokality Předboj (svrchní cenoman). [Regular echinoid from locality Předboj (Upper Cenomanian)]. - Zprávy o geologických výzkumech v roce 1991, 25: 151-153. (in Czech with English summary)

Žítt, J., Geys, J. F. (2003): Novasalenia gen. nov.: a remarkable Late Cenomanian echinoid from the Bohemian Cretaceous Basin (Czech Republic). Cretaceous Research, 24(1): 23-30. http://dx.doi.org/10.1016/S0195-6671(03)00022-3

Žítt, J., Kopáčová, M., Nekovařík, Č. (2003): Epibionts of mollusc shells from the Korycany limestones (Upper Cenomanian, Czech Republic). - Bulletin of the Czech Geological Survey, 78(1): 41-52.

Žítt, J., Nekvasilová, O. (1993): Octocoral encrusters of rock substrates in the Upper Cretaceous of Bohemia. - Journal of the Czech Geological Society, 38: 71-78.

Žítt, J., Nekvasilová, O. (1996): Epibionts, their hard-rock substrates, and phosphogenesis during the Cenomanian-Turonian boundary interval (Bohemian Cretaceous Basin, Czech Republic). - Cretaceous Research, 17: 715-739. http://dx.doi.org/10.1006/cres.1996.0038

Žítt, J., Nekvasilová, O., Hradecká, L., Svobodová, M., Záruba, B. (1999): Rocky coast facies of the Unhošt' Tursko High (late Cenomanian - early Turonian, Bohemian Cretaceous Basin). - Acta Musei Nationalis Pragae, Series B, Historia naturalis, 54(3-4): 79-116.

Žítt, J., Vodrážka, R., Hradecká, L., Svobodová, M., Zágoršek, K. (2006): Late Cretaceous environments and communities as recorded at Chrtníky (Bohemian Cretaceous Basin, Czech Republic). - Bulletin of Geosciences, 81(1): 43-79. http://dx.doi.org/10.3140/bull.geosci.2006.01.043 


\section{Explanation of plates}

\section{PLATE 1}

1. Glomerula serpentina (GOLDFUSS, 1831), the specimen is attached to an oyster valve, (NM-O7544).

2. Neovermilia cf. ampullacea (J. DE C. SOWERBY, 1829), fragment of the free anterior tube portion, (NM-O7545).

3. Dorsoserpula bipartita (REUSs, 1845), tube coiled around a no longer preserved substrate, possibly a crinoid stem or a stem of an alga, (NM-O7546).

4. Dorsoserpula bipartita (REuss, 1845), underside of coil (= lateral view of tube), with the posterior tube portion forming a kind of "apex" in the centre, (NM-O7547).

5. Dorsoserpula bipartita (REUSs, 1845), coil, (NM-O7548).

6. Filogranula cincta (GoldFuss, 1831), upper side, (NM-O7549).

7. Two tubes of Laqueoserpula reussi (WEINZETTL, 1910), upper side of the larger specimen showing anterior tube portion, encrusted by a small tube, (NM-O7550).

8. Placostegus zbyslavus (ZIEGLER, 1984), coiled posterior tube portion and steeply elevated anterior portion, (NM-O7551).

9. Placostegus rigidus (REGENHARDT, 1961), anterior tube portion, encrusted by a coiled tube of Dorsoserpula bipartita (REUSs, 1845), (NM-O7552).

10. Placostegus rigidus (REGENHARDT, 1961), small tube fragment, encrusted by a now damaged coiled tube of Dorsoserpula bipartita (REUSs, 1845), (NM-O7553).

11. Cementula sp., anterior parts of the attached tube portions of two tubes attached to each other, (NM-O7554).

Scale bars are $2 \mathrm{~mm}$ in Fig. $1-2$ and 9 and $1 \mathrm{~mm}$ in Fig. 3-8 and $10-11$.

\section{PLATE 2}

1. Pyrgopolon (Septenaria) zitti sp. nov., holotype, attached to an oyster valve, upper side, (NM-O7555).

2. Pyrgopolon (Septenaria) zitti sp. nov., paratype, attached to an oyster valve, upper side, (NM-O7556).

3. Pyrgopolon (Septenaria) zitti sp. nov., paratype, two tubes attached to a Spondylus valve and to each other, upper sides, (NM-O7557).

4. Pyrgopolon (Septenaria) zitti sp. nov., paratype, two tubes attached to each other, cross-sections. The tube seen in the lowerpart of the photograph shows depressions which may be tubulae (inner basal-lateral channels), whereas the tube seen in the upper part of the photograph possesses "Favosites structure", (NM-O7558).

5. Pyrgopolon (Septenaria) nekvasilovae sp. nov., attached to an oyster valve, upper side, (NM-O7559).

6. Pyrgopolon (Septenaria) nekvasilovae sp. nov., lateral view of attached posterior tube portion and elevated free anterior portion, (NM-O7560).

7. Pyrgopolon (Septenaria) nekvasilovae sp. nov., holotype, $\mathrm{a}$ - cross-section of anterior tube portion showing the five keels, b - upper side, (NM-O7561).

8. Pyrgopolon (Septenaria) cf. tricostata (GoldFuss, 1841), a - aperture, b - upper side, (NM-O7562).

9. Pyrgopolon (Septenaria) cf. tricostata (GoldFuss, 1841), $\mathrm{a}$ - cross-section, $\mathrm{b}$ - upper side, (NM-O7563).
10. Pyrgopolon (Septenaria) sp., encrusted by two Placostegus sp. tubes, a - upper side, b - lateral view, (NM-O7564).

11. Pyrgopolon subgen. et sp. indet., a - aperture, b - upper side, (NM-O7565)

12. Pyrgopolon subgen. et sp. indet., anterior tube portion, upper side, showing many borings, (NM-O7566).

Scale bars are $5 \mathrm{~mm}$ in Fig. 1-7 and 9-12 and $4 \mathrm{~mm}$ in Fig. 8.

\section{PLATE 3}

1. Neomicrorbis crenatostriatus subrugosus (MÜNSTER in GoldFuss, 1831), a small spiral tube attached to the dorsal valve of a brachiopod, Cyclothyris aff. difformis (VALENCIENNES in LAMARCK, 1819), upper side, (NM-O7567).

2. Dorsoserpula bipartita (REUSS, 1845), a curved but not coiled tube attached to a valve of the brachiopod Phaseolina phaseolina (VALENCIENNES in LAMARCK, 1819), upper side, (NM-O7568).

3. Neovermilia cf. ampullacea (J. DE C. Sowerby, 1829), tube encrusted by membranipore bryozoa, upper side, (NM-O7569).

4. Placostegus rigidus (REgenhardT, 1961), anterior tube portion with very short elevated free portion, posterior tube portion damaged, attached to poorly preserved bryozoan stem, oblique view to upper side and aperture, (NM-O7570).

5. Pyrgopolon (Septenaria) zitti sp. nov., paratype, eight tubes attached to spondylid valve and to each other, upper sides and cross-sections, (NM-O7571).

Scale bars are $2 \mathrm{~mm}$ in Fig. 1 and $5 \mathrm{~mm}$ in Fig. 2-5.

\section{PLATE 4}

1. Neovermilia cf. ampullacea (J. de C. SOWERBY, 1829), a upper side, $\mathrm{b}$ - underside of formerly attached tube portion, A, B - arrows point to an area with many borings into the tube wall, (NM-O7572).

2. Pyrgopolon (Septenaria) cf. tricostata (GoldFuss, 1831), anterior tube portion with borings and holes, A - arrows point to small borings similar to those in Fig. 1, present in all surfaces of the tube wall, B, C - arrows point to large holes caused by the growing serpulid tube around stolons of the hydroid symbiont Protulophila gestroi ROVERETO, 1901, (NM-O7573).

Scale bars are $5 \mathrm{~mm}$ in Fig. 1 and $1 \mathrm{~mm}$ in Fig. 2. 
PLATE 1

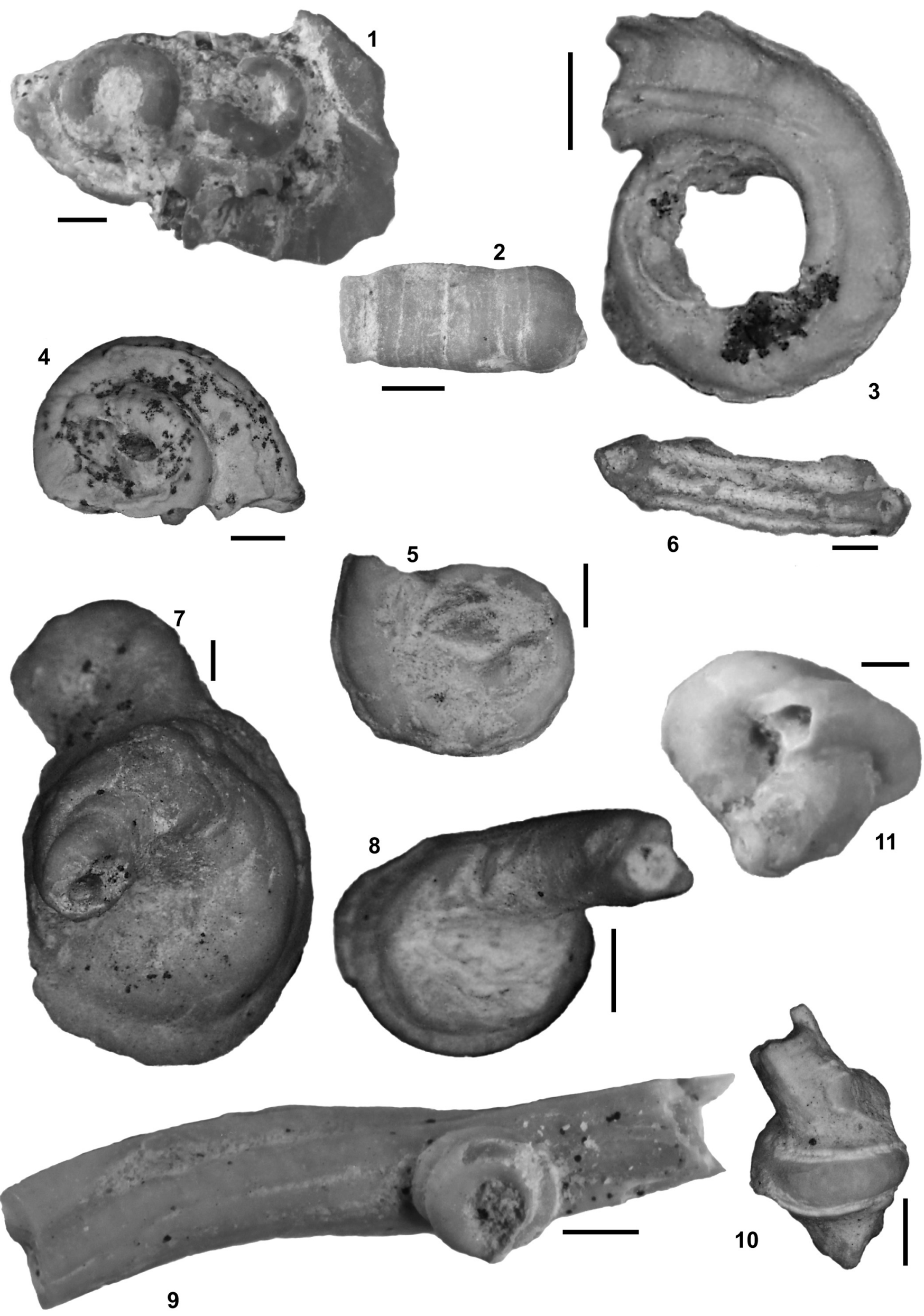


PLATE 2
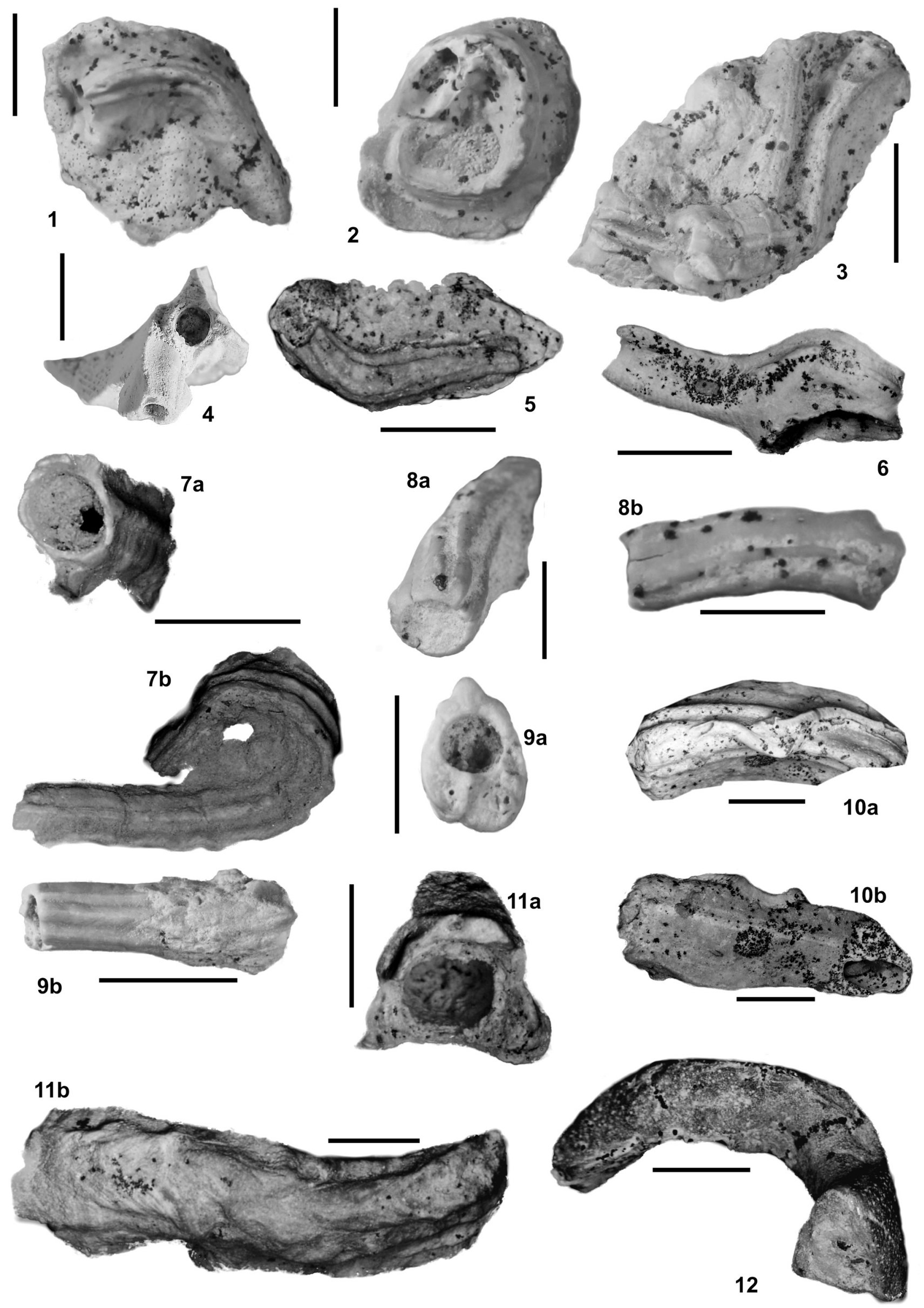
PLATE 3
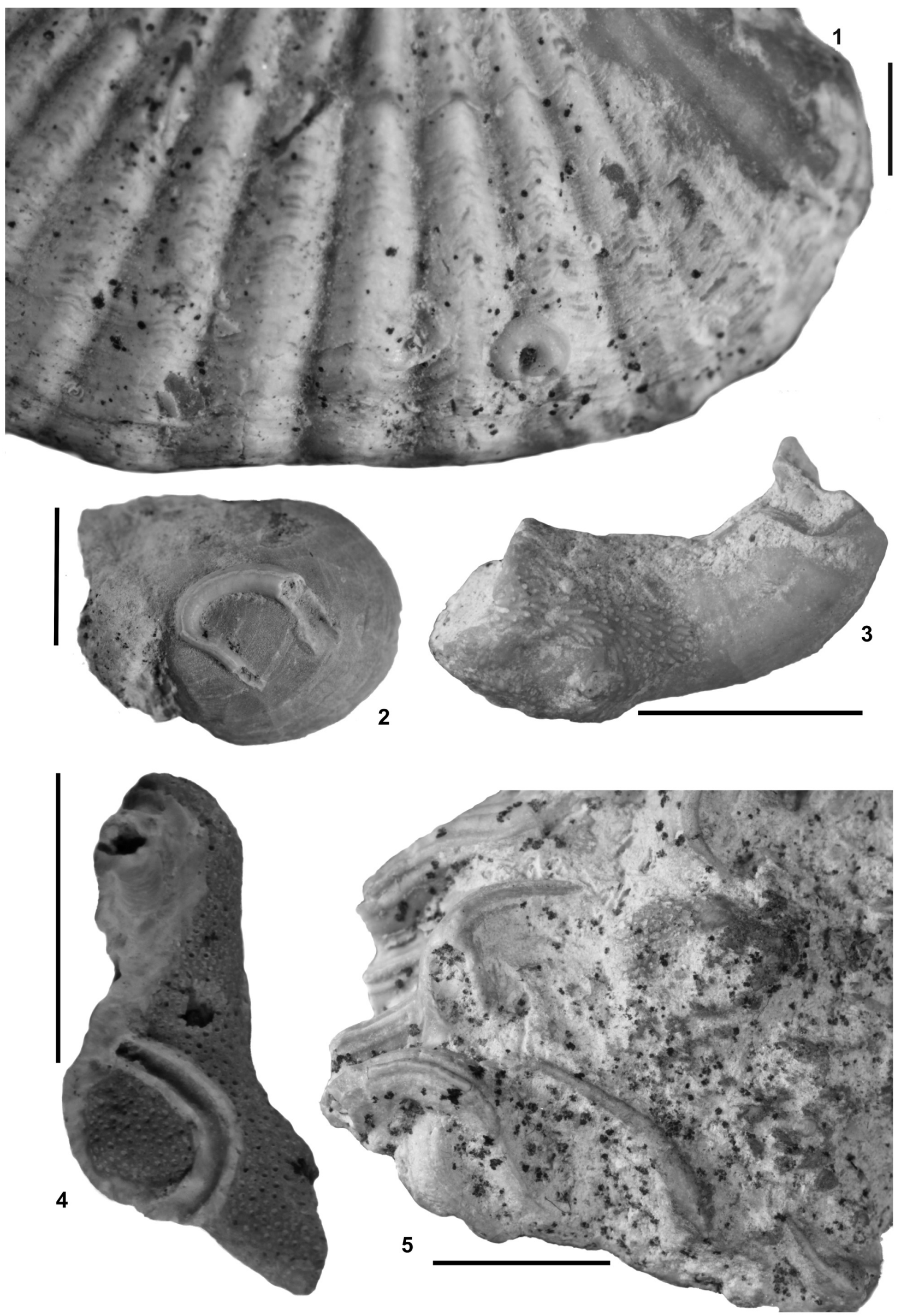
PLATE 4
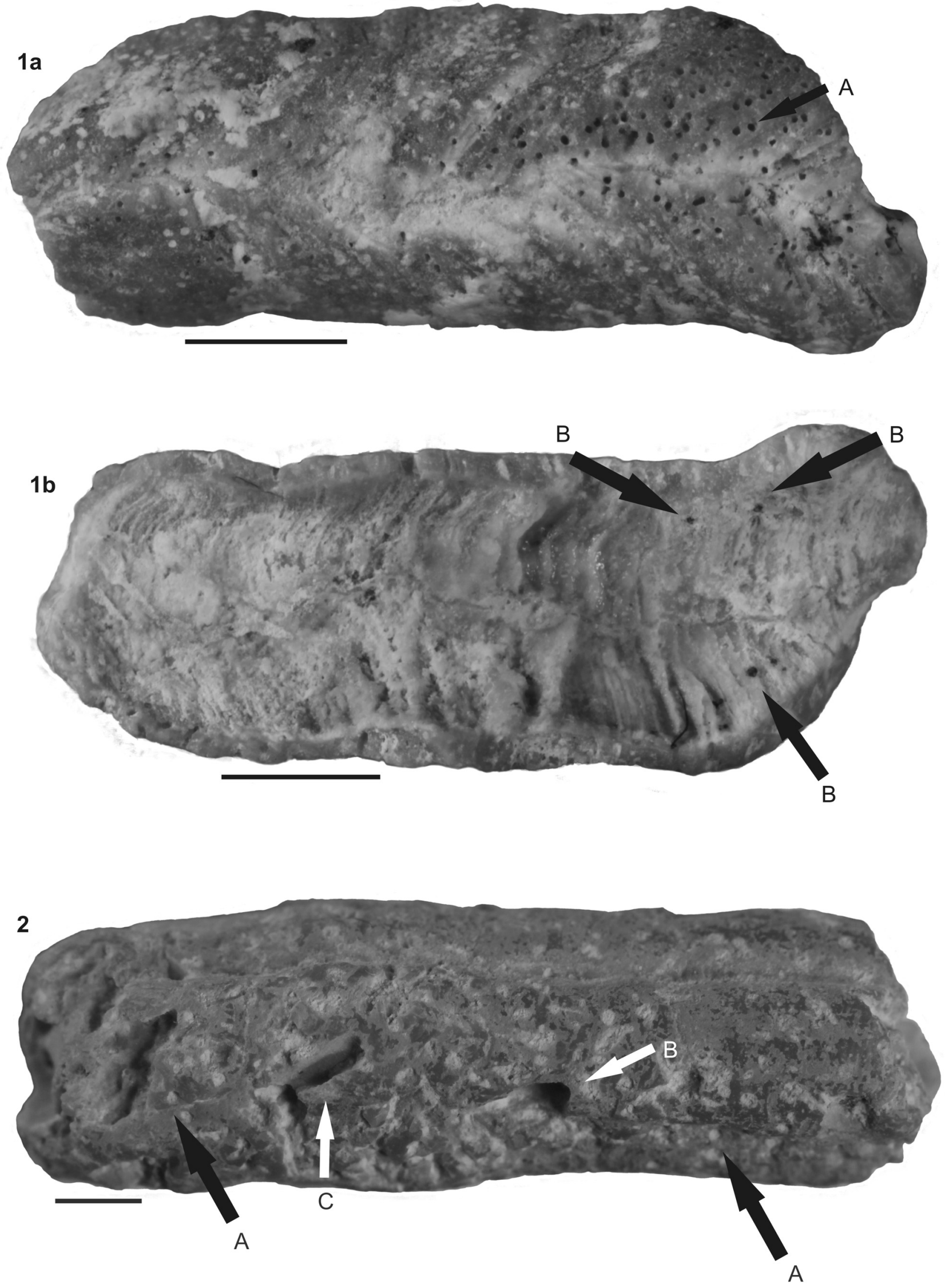